\title{
Roman versus Jewish Reckoning of Hours in the Gospel of John: An Exegetical Misconception That Refuses to Die
}

\author{
ADAM KUBIŚ \\ The John Paul II Catholic University of Lublin \\ adamkubis@kul.pl \\ ORCID: 0000-0003-4961-2254
}

\begin{abstract}
The article deals with an exegetical misunderstanding revolving around the purported existence of two different ways of reckoning the hours of the day in antiquity, and consequently in the Gospels: an alleged Roman mode (in John's Gospel) and the Jewish one (in the Synoptics). Among Johannine scholars a disagreement exists over the issue of which system was embraced by the Evangelist. While the majority claim that John followed the known Jewish system of reckoning hours, a minority argue that another, distinctively Roman system was being employed in the FG. In its first part, the article reviews extrabiblical ancient literature to demonstrate that, while the Romans in fact had two systems of marking the beginning of the day (dies civilis, legitimus - starting at midnight, and dies naturalis, verus - starting at sunrise), the manner of reckoning the hours of the day (and the night) was precisely the same for the Romans as for the Jews. In the second part, both systems are applied to four specific Johannine references to the hours of the day $(1: 39 ; 4: 6 ; 4: 52$; and 19:14) in order to assess which method of reckoning the hours better suits the literary context of each narrative. While this internal analysis of the Johannine text is inconclusive, our assessment of the external, extrabiblical evidence points to the conclusion that the ancients, including John the Evangelist, used only one, nearly universal manner of reckoning the hours, i.e. beginning from sunrise.
\end{abstract}

KeYwORDs: the Gospel of John, hour, day, time reckoning, John 1:39; John 4:6; John 4:52; John 19:14

\section{Introduction: Thesis and Objectives}

The Gospel of John contains four precise references to the hours of the day: in 1:39 (the tenth hour); 4:6 (the sixth hour); 4:52 (the seventh hour) and 19:14 (the sixth hour). ${ }^{1}$ Some scholars working on the Gospel of John subscribe to the belief that in antiquity two distinct systems of counting the hours of the day existed,

1 This chronological information about precise hours is to be differentiated from the Johannine theological meaning of the lexeme "hour" elsewhere in the FG. On the latter specifically theological meaning, see G. Ferraro, L' "ora" di Cristo nel quarto vangelo (Aloisiana 10; Roma: Herder 1974); S. Mihalios, The Danielic Eschatological Hour in the Johannine Literature (LNTS 436; London- 
namely the Roman one and the Jewish. In the former, called Roman (or sometimes Egyptian), hours are counted from midnight to noon (then another 12 hours, noon to midnight). In the latter system, termed Jewish (or Babylonian), the twelve hours of night are counted from sunset to sunrise, and the twelve hours of day from sunrise to sunset. ${ }^{2}$ This article will argue that, while the Romans did indeed have a system of setting the beginning of a day (understood as a 24-hour day) at midnight, they always counted the hours of the day from sunrise. The latter was a system widespread throughout the ancient world, and not limited to the Romans only. Most importantly, however, the Romans differentiated between a civil day (an official, legal 24-hour day) and a natural day (a roughly 12-hour-long period of daylight). The beginning of the former was set at midnight, while the beginning of the latter was at sunrise. While biblical scholars are mostly aware of the two-fold understanding of "day" in Roman sources (civil versus natural day), they do not seem to understand the distinction between the Roman reckoning of days and the reckoning of hours. Lack of such awareness has led to a faulty belief in the existence of two systems of counting the hours of the day. As a result, Johannine scholars and translators can be divided into supporters of either the "Roman" or the "Jewish" system of reckoning hours, with the vast majority embracing the Jewish system and a minority supporting a supposed Roman one. Not surprisingly, several other authors refuse to make any firm choice in the matter either way. ${ }^{3}$

The "Roman hypothesis" seems to be a relative novelty in the exegesis of the Gospel of John. Arthur Wright argues that the Roman way of counting

New York: Clark 2011); B. Jojko, "The Hour of Jesus and the Wedding Feast at Cana (John 2:1-11)," VV 38/1 (2020) 125-147.

2 For example, see a new commentary on the FG: W.F. Cook, John. Jesus Christ is God (The Focus on the Bible Commentary Series; Fearn, Ross-shire, Scotland, U.K.: Christian Focus 2016) 34, n. 3: "The Jewish people counted the hours of the day from dawn, while the Romans counted the hours of the day from midnight on."

3 E.g. C.K. Barrett, The Gospel According to St John. An Introduction with Commentary and Notes on the Greek Text, 2 ed. (London: SPCK 1978) 231. Robert Utley (The Beloved Disciple's Memoirs and Letters. The Gospel of John, I, II, and III John [SGCS.NT 4; Marshall, TX: Bible Lessons International 1999] 19) believes that John uses various systems of counting the hours in various parts of his Gospel: "It is uncertain whether John is using Roman time, beginning at (1) 12:00 a.m. or (2) day break, or Jewish time, beginning at 6:00 p.m. (twilight). When one compares John 19:14 with Mark 15:25 it seems to imply Roman time. However, when one looks at John 11:9 it seems to imply Jewish time. John possibly used both." Referring to the tenth hour in John 1:39, he leaves room for both options: "Here it seems to be Roman time, \#2, or about 4:00 p.m." A similar refusal to take a stance as to the tenth hour in John 1:39 is present in, e.g., W.A. O'Conor, A Commentary on the Gospel of St. John (London: Longmans - Green 1874) 20; A. Barnes, Notes on the New Testament. Luke and John (London: Blackie \& Son 1885) 187; R.H. Mounce, "John," The Expositor's Bible Commentary. Revised Edition. X. Luke - Acts (eds. T. Longman III - D.E. Garland) (Grand Rapids, MI: Zondervan 2007) 382. 
the hours from midnight "was unknown to the ancient fathers." "The belief that John used Roman time was first articulated by George Hutcheson in his 1657 explanation of the sixth hour in John 19:14. ${ }^{5}$ The Roman hypothesis became immensely popular in the 18th and 19th centuries and, as it turns out, still has its supporters today, ${ }^{6}$ being embraced by some contemporary translators of the Gospel of John. ${ }^{7}$ The "Roman hypothesis" is thus still alive among Johannine commentators and translators.

One's espousal of one or the other system of reckoning the time in all four of John's references to the hour of the day has definite interpretational consequences. The significance of the subject of this study will be illustrated through two examples, one somewhat trivial but the other exegetically crucial.

4 A. Wright, Some New Testament Problems (The Churchman's Library; London: Methuen 1898) 150. Roman time is not used even in the writings of Irenaeus of Lyon (died $202 \mathrm{CE}$ ), despite the fact that Irenaeus came from Asia Minor, where - as corroborated by the martyrs' testimonies - the system was well known and used. Leon Morris (The Gospel According to John. Revised Edition [NICNT; Grand Rapids, MI: Eerdmans 1995] 138) also draws attention to the fact that early Christian authors interpreted John's tenth hour in 1:39 according to the Jewish system, that is, as an hour in the afternoon. For example, John Chrysostom (died 407 CE) interprets John's tenth hour (1:39) as evening time "for the sun was already near its setting" (Hom. in Joh. 18,3; after P. Schaff (ed.), A Select Library of the Nicene and Post-Nicene Fathers of the Christian Church. XIV. Saint Chrysostom. Homilies on the Gospel of St. John and the Epistle of Hebrews [New York: Christian Literature 1889] 65).

5 G. Hutcheson, An Exposition of the Gospel of Jesus Christ According to John (London: Smith 1657) 398 .

6 Some $19^{\text {th }}$-century authors are enumerated by J.P. Lange, The Gospel According to John (A Commentary on the Holy Scriptures. New Testament 3; New York: Scribner 1871) 93. As far as contemporary authors are concerned, the following need to be mentioned: B.F. Westcott, The Gospel According to St. John. The Authorized Version with Introduction and Notes (London: Murray 1882) 282; A.T. Robertson, Word Pictures in the New Testament. V. The Fourth Gospel (Nashville, TN: Broadman 1932) ad loc. John 1:39; W. Hendriksen, Exposition of the Gospel According to John (BNTC; Grand Rapids, MI: Baker Book House 1953, reprint 2002) 104-105 (he also mentions other scholars in favor of this view); N. Walker, "The Reckoning of Hours in the Fourth Gospel," NovT 4 (1960) 69-73; E.A. Blum, "John," The Bible Knowledge Commentary. An Exposition of the Scriptures by Dallas Seminary Faculty. Old Testament and New Testament Edition Based on the New International Version (eds. J.F. Walvoord - R.B. Zuck) (Wheaton, IL: Victor Books 1983) II, 275; R.A. Culpepper, Anatomy of the Fourth Gospel. A Study in Literary Design (Philadelphia, PA: Fortress 1983) 219; W.W. Wiersbe, The Bible Exposition Commentary (Wheaton, IL: Victor Books 1996) 288, 299, 303 , 381; R.H. Gundry, Commentary on the New Testament. Verse-by-Verse Explanations with a Literal Translation (Peabody, MA: Hendrickson 2010) 354, 365, 371, 451.

7 Holman Christian Standard Bible (CSBO 2005); New American Standard Bible (NASB 1977, 1995). CSBO translates John 1:39 in the following way: "It was about 10 in the morning." In the footnote to this verse, one reads: "Various methods of reckoning time were used in the ancient world. John probably used a different method from the other 3 Gospels." The modern translator implies that the synoptic gospels used the Jewish reckoning, while John's Gospel - the Roman one. The text of John 4:6 is translated as "It was about six in the evening." Consequently, in 4:52 one reads "at seven in the morning" and in 19:14 "it was about six in the morning." NASB (1995) adds a footnote to each of John's four references to precise hours in which the Roman way of reckoning is suggested, e.g. 1:39: "Perhaps 10 a.m. (Roman time)." 


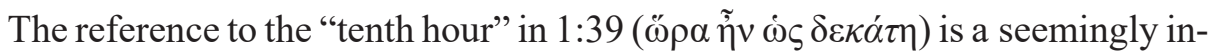
cidental element of the narrative. ${ }^{8}$ If the gospel's author followed the Roman system, the tenth hour would correspond to $10 \mathrm{a}$.m. If, however, he employed the Jewish system, the tenth hour would be 4 p.m. ${ }^{9}$ The text seems more logical if one were to accept the first - that is, Roman - alternative, as it mentions two disciples of John the Baptist staying with Jesus "that day" ( Then, the disciples would spend the whole day with Jesus, from the morning (10 a.m.) to the evening. On the same day, Andrew has time to bring Peter to Jesus $(1: 40-42)$. If one were to espouse the second - i.e., Jewish - option, then the two disciples would spend only two hours with Jesus (from 4 p.m. to sunset at 6 p.m.). It cannot be ruled out, however, that they spent the whole evening or even night with Jesus. ${ }^{10}$ It would nevertheless remain difficult to understand the references both to their staying with Jesus "that day" and to Peter being brought to Jesus.

From the point of view of scholarship on the relationship between the Gospel of John and the synoptic gospels, a key role is played by the reference to

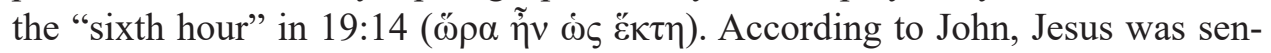
tenced to death at this time. According to Mark, however, Jesus was crucified

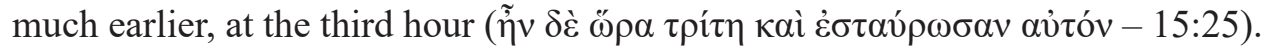
The discrepancy between the two accounts has generated a plethora of hypotheses, prominent among these being the conviction that two systems of reckoning hours must have existed in the ancient world. Following this reasoning, John would be employing the Roman system, thus his sixth hour would refer to dawn, or 6 a.m. The synoptics, by contrast, are embracing the Jewish system, thus Mark's third hour would correspond to 9 a.m. This hypothesis makes it possible to reconcile Mark's and John's narratives: there is enough time between the sentencing (at 6 a.m.) and the crucifixion (at 9 a.m.) to allow for the narrative events, including Jesus' trek to Golgotha. This one example shows that a bit of well-intentioned, scholarly conjecture regarding the system of reckoning hours in the Gospel of John can have far-reaching exegetical consequences.

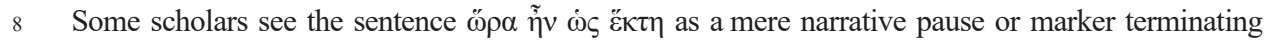
a narrative unit. See E. Haenchen, John 1. A Commentary on the Gospel of John, Chapters 1-6 (Hermeneia; Philadelphia, PA: Fortress 1984) 159 ("[it] marks the end of the narrative unit"); X. LéonDufour, Lecture de l'Évangile selon Jean. IV. L'heure de la glorification (chapitres 18-21) (Paris: Seuil 1996) 190; J. Frey, Die johanneische Eschatologie. II. Das johanneische Zeitverständnis (WUNT 110; Tübingen: Mohr Siebeck 1998) 190-191.

9 William Hendriksen (Exposition, 104) posits that John's tenth hour can even be understood as 10 p.m.: "the expression 'the tenth hour' can mean 4 P. M. or 10 A. M. or even 10 P. M. However, the context makes it quite impossible to think of 10 P. M." This proposal is without grounds, however, as no ancient system of reckoning the hours of the day (and night) beginning with noon is known.

10 Both possibilities are presented by J.-A. Brant, John (Paideia; Grand Rapids, MI: Baker Academic 2011) 51: "If one begins counting at dawn, the tenth hour means that it is late in the afternoon, and so, perhaps, the disciples remain with Jesus overnight. If it signifies the Egyptian method of counting from midnight, it signifies that the disciples spent the whole day with him." 
This article discusses some arguments made in favor of John's use of a purported Roman system of reckoning hours, as well as the arguments against it, which, of necessity, would suggest the author's use of the known Jewish system. For the sake of clarity (and of argument), the article will sometimes use the expressions "Roman hypothesis" and "Jewish hypothesis" for the two methods of counting. The article aims to critically assess these arguments and apply the two different systems to John's text. Such a goal imposes a tripartite structure upon the article: First, the arguments suggesting the existence in antiquity of both a Roman and a Jewish system of reckoning hours will be presented and assessed. Then, the two hypotheses will be applied to each of the four references to the hours of the day present in John's Gospel.

\section{Arguments Supporting the Existence of a Roman System of Reckoning Hours}

Supporters of the Roman hypothesis refer to arguments of three kinds. The first is citing the texts of ancient authors that seem to corroborate the reckoning of hours since midnight. Thus, I first present four texts which address the way in which the Romans marked the beginning of a new day, and then four texts that speak to the Romans' division of the day into hours. The two further arguments often employed, those relating to the place and time of the creation of the Fourth Gospel, will likewise be explored through texts. Taken together, these can be termed a geographical-chronological argument.

\subsection{Texts}

Pliny the Elder. Supporters of the Roman hypothesis frequently refer to Pliny the Elder (23-79 CE), who in his Naturalis Historia (II, 79, § 188) maintains that the Babylonians count the hours between two dawns; the Athenians, between two sunrises ${ }^{11}$ the inhabitants of Umbria, from noon to noon; ordinary people all over the world, from dawn till dusk; and Roman priests and authorities responsible for the establishment of official days (dies civilis), including the Egyptians and Hip-

11 Apart from the Athenians, the system of counting the hours of the day from sunset was used in antiquity also by the nomadic peoples of Libya (Joannes Stobaeus, Anthologium 4,2,25,74-75:

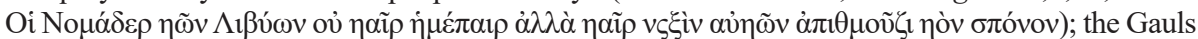
(Caesar, De Bell Gall., 6); and the Germanic peoples (Tacit, Ger.). After W. Maude, De Die Natale, by Censorinus (New York: Cambridge Encyclopedia 1900) 37, n. 106. 
parchus of Nicaea $\left(2^{\text {nd }}\right.$ century BCE Greek mathematician, geographer and astronomer), from midnight till midnight. Pliny's original Latin text reads as follows:

Ipsum diem alii aliter observavere, Babyloni inter duos solis exortus, Athenienses inter duos occasus, Umbri a meridie ad meridiem, vulgus omne a luce ad tenebras, sacerdotes Romani et qui diem diffiniere civilem, item Aegypti et Hipparchus, a media nocte in mediam (LCL 330, 318 and 320). ${ }^{12}$

Pliny the Elder does not indicate, however, that the hours of the day were counted from midnight, but merely shows that midnight marked the beginning of a new day. What is more, the text makes it clear that "common people everywhere" (vulgus omne) count the hours from dawn till dusk (a luce ad tenebras). ${ }^{13}$

Plutarch of Chaeronea. In his The Roman Questions (Quaestiones Romanae), Plutarch of Chaeronea (circa 46-119 CE) asks at the beginning of question 84:

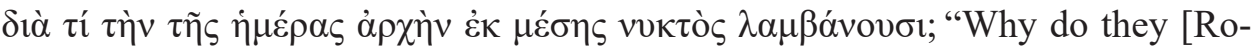
mans] reckon the beginning of the day from midnight?" (LCL 305, 128-129). We can note that in neither the question nor the answer does Plutarch focus on when the counting of the hours of the day begins. In his response, Plutarch claims that for the majority of people the beginning of the day is marked by the appearance of the first rays of the sun above the horizon, while the disappearance of the last ray signals the beginning of the night. ${ }^{14}$

Aulus Gellius. Another ancient text frequently referred to in support of the Roman hypothesis is that of Aulus Gellius, a Roman author and grammarian living circa 125-180 CE. In his work Noctes Atticae (Book III, Chapter II), Aulus Gellius makes reference to the text Rerum humanarum, authored by Marcus Varro, who lived two centuries earlier (116-27 BCE) and who, in his treaty De Diebus $(13,2)$, likewise subscribes to the reckoning of days from midnight to midnight. Both Marcus Varro and Aulus Gellius discuss the date of birth of

12 The English translation: "The actual period of a day has been differently kept by different people: the Babylonians count the period between two sunrises, the Athenians that between two sunsets, the Umbrians from midday to midday, the common people everywhere from dawn to dark, the Roman priests and the authorities who fixed the official day, and also the Egyptians and Hipparchus, the period from midnight to midnight" (LCL 330, 319 and 321).

13 F.F. Bruce, The Gospel of John. Introduction, Exposition and Notes (Grand Rapids, MI: Eerdmans 1983) 66, n. 56; D.A. Carson, The Gospel According to John (The Pillar New Testament Commentary; Grand Rapids, MI - Cambridge, U.K.: Eerdmans 1990) 157.

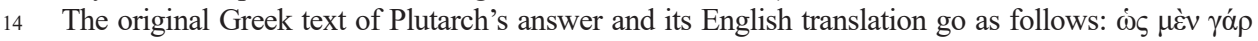



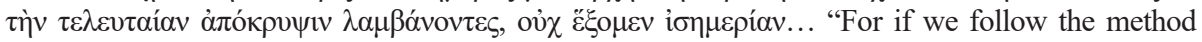
by which most people formulate their definitions, by their perceptions, reckoning the first peep of the sun above the horizon as the beginning of day, and the cutting off of its last rays as the beginning of night, we shall have no equinox" (LCL 305, 128-129). 
a person born during the night. ${ }^{15}$ In such a case, the reckoning of days from sunrise till sunset was pointless. Marcus Varro, and Aulus Gellius after him, argue that a person born after midnight was born on the day that began with the sunrise of the subsequent day. A person born before midnight, however, was born on the day that ended with the sunset of a few hours before. Aulus Gellius' original text reads:

QUAERI solitum est, qui noctis hora tertia quartave sive qua alia nati sunt, uter dies natalis haberi appellarique debeat, isne quem nox ea consecuta est, an qui dies noctem consecutus est. M. Varro in libro Rerum humanarum, quem De Diebus scripsit, homines, inquit, qui inde a media nocte ad proximam mediam noctem in his horis viginti quattuor nati sunt, uno die nati dicuntur. Quibus verbis ita videtur dierum observationem divisisse, ut qui post solem occasum ante mediam noctem natus sit, is ei dies natalis sit, a quo die ea nox coeperit; contra vero, qui in sex noctis horis posterioribus nascatur, eo die videri natum, qui post eam noctem diluxerit (LCL 195, 238 and 240). ${ }^{16}$

In the subsequent fragment of his work (II, 4-6), referring once again to Marcus Varro's book (libro), Aulus Gellius speaks of a different reckoning of days among the Athenians, who count the day from sunset to sunset. He then mentions the Babylonians, who count the day from sunrise to sunrise. According to Varro, the system used by the Umbrians is absurd, for they count days from noon to noon. Aulus Gellius goes on to argue (II, 7) that the way of reckoning days from midnight to midnight used by the Romans (populum Romanum) is corroborated by multiple arguments (multis argumentis). The first of these deals with Roman religious ceremonies (II, 8-9). The celebrations are determined according to days, even when they take place at night. If a religious celebration takes place within the final six hours of the night, according to the Romans, it takes place on the day that begins at dawn after the night in question. Aulus Gellius subsequently (II, 10-11) refers to the taking and giving back of loans on the same day.

15 Anthony T. Grafton ("Time-reckoning," The Oxford Companion to Classical Civilization, 2 ed. [eds. S. Hornblower - A. Spawforth] [Oxford: Oxford University Press 2014] 793) notes that a preoccupation with the hour of birth was related to a growing interest in astrology: "Only in the $1^{\text {st }}$ cent. $\mathrm{BC}$ and after, when the spread of astrology made it urgent to know the year, day, and hour of an individual's birth, did an interest in precise calendar dates become widespread outside scientific circles."

16 English translation of this text: "It is often inquired which day should be considered and called the birthday of those who are born in the third, the fourth, or any other hour of the night; that is, whether it is the day that preceded, or the day that followed, that night. Marcus Varro, in that book of his Human Antiquities which he wrote On Days, says: Persons who are born during the twentyfour hours between one midnight and the next midnight are considered to have been born on one and the same day. From these words it appears that he so apportioned the reckoning of the days, that the birthday of one who is born after sunset, but before midnight, is the day after which that night began; but that, on the other hand, one who is born during the last six hours of the night is considered to have been born on the day which dawned after that night" (LCL 195, 239 and 241). 
If a loan is taken after midnight and repaid in the afternoon, such a transaction will commonly be understood to transpire within one day. Another example is that of plebeian tribunes (tribuni plebei), who may not leave Rome for more than one (full) day. If a tribune leaves Rome after midnight and comes back after sunset, his absence is not considered to be day-long, as he returned to the city before the end of the sixth hour after sunset, that is, before midnight. Aulus Gellius uses here the expression "before the sixth hour of the night" (ante horam noctis sextam), clearly indicating that the hours of the night are counted from sunset. In the subsequent part of Book III, Chapter II, Aulus Gellius refers also to an example taken from the legal work by Quintus Mucius, and to an excerpt from Virgil's poem (Aen. 5,738). He concludes by saying that "the day which the Romans have called 'civil' begins after the completion of the sixth hour of the night" (III, II, 16; LCL 195, 245). ${ }^{17}$

The examples referenced by Aulus Gellius prove without a shadow of a doubt that the Romans counted days from midnight to midnight. It is impossible, however, to infer that they calculated the hours of the day and night in the same way. In fact, the texts discussed above clearly show, at least twice (Noctes Atticae, III, II, 11 and III, II, 16), that night hours were counted from sunset and not from midnight.

Censorinus. The same four ways of reckoning the beginning and end of a day in antiquity are described in a later work by Censorinus, The Birthday Book for Quintus Caerellius (De Die Natali Liber ad Quintum Caerellium), published in $238 \mathrm{CE}$. The Roman grammarian and writer mentions the Babylonians, who count the day from sunrise to sunrise; the Umbrians, for whom one day lasts from noon to noon; the Athenians, who count the day from sunset to sunset; and the Romans, who count from midnight till midnight $(23,3)$. Later, Censorinus adds that the Roman system was used to regulate public ceremonies and auspices performed by officials $(23,4)$ and to determine a child's date of birth $(23,5)$. Significantly, Censorinus adds that the division of the day - and the night, for that matter - into twelve hours is well known and accepted: "In horas XII diem divisum esse noctemque in totidem vulgo notum est" $(23,6)$. According to Censorinus, the day's division into twelve hours was introduced only after sundials (reperta solaria) began to be used, the first three of which were placed by the temple of Quirinus, in the Capitoline, and near the temple of Diana on the Aventine $(23,6) .{ }^{18}$ Then Consul Manius Valerius (263 BCE) imported a sundial from Sicily and had it placed on a column near the Rostra, a lectern in the Forum Romanum. Sicily's

17 In Latin: “diem quem Romani ‘civilem' appellaverunt a sexta noctis hora oriri” (LCL 195, 244).

18 According to Pliny the Elder (Naturalis Historia VII, 60 § 213), the first sun clock (solarium horologium) was built at the temple of Quirinus by Papirius Cursor in circa 291 BCE. This fact is mentioned also by Livy (Ad Urbe Condita Libri x.39-47, viii, ix) and Eutropius (Breviarium Historiae Romanae II, 8,9). 
latitude, however, is not the same as Rome's, and for this reason Philippus Marcius Lucius (censor in 86 and consul in $91 \mathrm{BCE}$ ) had a new sundial placed next to the original, one that corresponded to Rome's geographical position. Censorinus mentions also a water clock (horarium) constructed in Rome in $159 \mathrm{BCE}$, called a solarium "because of the usual way of telling the hours by the sun" $(23,7)$. He nevertheless concludes (perhaps somewhat inaccurately) that "It is likely that the word 'hour' was not used at Rome for at least 300 years" $(23,8)$. This is corroborated by The Laws of the Twelve Tables, written in 451-449 BCE, which fails to mention the word "hour." Instead the phrase "before noon" or "before the half-day" (ante meridiem) appears, signaling the division of the day into two halves $(23,8)$. At the end of the chapter, Censorinus makes an important comment claiming that some divide both the day and the night into four parts each. Evidence of that is provided by military language, in which the night is divided into four watches $(23,9) .{ }^{19}$

At the beginning of his text $(23,1-2)$ Censorinus makes a clear distinction between a civil day (dies civilis) and a natural day (dies naturalis). He defines the latter very precisely as time between sunrise and sunset: "Naturaliter dies est tempus ab exoriente sole ad solis occasum" $(23,2)$. The civil day, however, encompasses both the natural day (dies verus) and the night: "Civiliter autem dies vocatur tempus, quod fit uno caeli circumactu, quo dies verus et nox continetur" $(23,2)$. Elsewhere Censorinus adds that midnight (nox media) "is both the end and the beginning of the Roman day" (tempus principium et postremum est diei Romani) $(24,1)$. Censorinus' text clearly distinguishes, however, between the reckoning of days (determining the beginning and end of a day) and the reckoning of hours. In his view, the division into twelve hours of the day is related to the invention of the sundial. Earlier, in the 5th century BCE, the notion of an hour was not known and it can be assumed that days were divided into two or four parts. Though not all of Censorinus' work has survived to the present day, the final sentences of the extant text claim that the Romans treated sunset, and not midnight, as the end of the natural day:

though many think that the final hour is after the sun sets, because in the Twelve Tables it is written: 'Sunset shall be the final time of the day.' But later, M. Plaetorius, when he was tribune, passed a plebiscite, in which it was written: 'The current praetor of the city, and any later ones,

19 For the English text see H.N. Parker, Censorinus. The Birthday Book (Chicago, IL: University of Chicago Press 2007) 54-55, and Maude, Censorinus, 36-38. The original Latin text is reproduced in the new critical edition by K. Brodersen (trans. and ed.), Censorinus. Über den Geburtstag. Lateinisch und Deutsch (Edition Antike; Darmstadt: Wissenschaftliche Buchgesellschaft 2012) ad loc. 
shall have two lictors with him, and let him give judgment among the citizens up to the final hour, that is, sunset' $(24,3) .^{20}$

Now, for insight specifically into the Roman reckoning of hours, we turn to yet other texts of ancient authors, four of which are discussed below.

Anonymous' De Bello Alexandrino. As we can read in De Bello Alexandrino (10), an anonymous work written circa $40 \mathrm{BCE}$, Caesar, to whom the authorship of the text is attributed, did not launch upon a certain battle for two reasons: first, his soldiers were not on board the ships, and secondly, it was already the tenth hour (horam X). As the subsequent sentence explains, battle at this time of day would not be prudent on account of the approaching night (nox), which could embolden the opponents. ${ }^{21}$ The only reasonable interpretation is that here the "tenth hour" is about 4 p.m.

Horace. One of the letters written by Horace (65-8 BCE) includes the information that dinner (cena) is a meal eaten after nine (nona) (Epistulae, I, 7,69-71). ${ }^{22}$ Thus, if one were calculating the hours from midnight, dinner would be served soon after 9 a.m. which, of course, is impossible.

Titus Livius. The description of the siege of the city of Sutrium included in The History of Rome (Ad urbe condita libri CXLII) by Titus Livius (59 BCE - 17 CE) also provides some insight into the way the Romans calculated the hours of the day. At the "tenth hour of the day" (decima errat fere diei hora) the commander made a speech and let the soldiers eat their meal (IX 37,5). After the meal the soldiers rested till the fourth night watch (quarta vigilia), and then they readied for battle (IX 37,8) (LCL 191, 306-307). The literary context of the expression makes it clear that the decima hora signified an hour in the afternoon.

20 Parker, Censorinus, 56. The Latin original: "quamvis plurimi supremam post occasum solis esse existimant, quia est in XII tabulis scriptum sic: 'solis occasus suprema tempestas esto'. Sed postea M. Plaetorius tribunus plebiscitum tulit, in quo scriptum est: 'praetor urbanus, qui nunc est quique posthac fuat, duo lictores apud se habeto usque supremam ad solem occasum iusque inter cives discito."”

21 The original Latin text states: "Qui duabus de causis eo die dimicare nolebat, quod et nullos milites in navibus habebat et post horam $\mathrm{X}$. diei res agebatur, nox autem allatura videbatur maiorem fiduciam illis, qui locorum notitia confidebant" (LCL 402, 22 and 24). In English translation by A.G. Way: "Now there were two reasons why Caesar was loth to fight an action that day: he had no troops on board; and it was now after the tenth hour as the matter now stood, and on the other hand nightfall would, he thought, inspire greater confidence in the enemy, who were relying on their local knowledge" (LCL 402, 23 and 25).

22 The original Latin text: "'sic ignovisse putato me tibi, si cenas hodie mecum.' 'ut libet.' 'ergo post nonam venies: nunc i, rem strenuus auge.' ut ventum ad cenam est, dicenda tacenda locutus tandem dormitum dimittitur" (LCL 194, 300). Its English translation by H. Rushton Fairclough (LCL 194, 301) goes as follows: “'You're to take it that I've pardoned you only if you sup with me to-day.' 'As you please.' 'You will come then after three o'clock. Now go, set to and add to your wealth!' On coming to supper, he chatted about anything and everything, and then at last was sent off to bed." 
Martial. The Latin poet Martial (circa 40-104 CE) described a day of a Roman in detail in one of his epigrams (Book IV, Epigram 8):

Prima salutantes atque altera conterit hora, exercet raucos tertia causidicos,

in quintam varios extendit Roma labores, sexta quies lassis, septima finis erit, sufficit in nonam nitidis octava palaestris, imperat extructos frangere nona toros: hora libellorum decuma est, Eupheme, meorum,

temperat ambrosias cum tua cura dapes et bonus aetherio laxatur nectare Caesar

ingentique tenet pocula parca manu.

Tunc admitte iocos: gressu timet ire licenti ad matutinum nostra Thalia Iovem (LCL 94, 266).
The first hour and the second tires out callers, the third busies hoarse barristers, Rome stretches her various tasks until the fifth, the sixth will be rest for the weary, the seventh the end thereof. The eight to the ninth suffices for the oily wrestling bouts. The ninth commands us to crush the piled-up couches. The tenth, Euphemus, is the hour of my little books, when your care governs the ambrosial feast and kindly Caesar relaxes with celestial nectar, holding temperate cups in his mighty hand. Then let in the jests. My Thalia is afraid to approach with presumptuous step a matutinal Jove (LCL 94, 267).

The division of the day in Martial's account leaves no doubt that the hours of the day were counted from dawn.

Conclusion. To summarize the data given above, the Roman method of determining the beginning of the day (dies civilis) at midnight was employed only by the authorities in legal matters and to interpret official documents, such as contracts or financial transactions. Counting the days from midnight also mattered for determining a person's date of birth and the times of religious ceremonies and auspices. Otherwise, the Romans followed the custom of counting the hours beginning from dawn, that is, approximately 6 a.m. ${ }^{23}$ At the end of the $19^{\text {th }}$ century, William M. Ramsay was already arguing that the belief in the existence of two ways of reckoning hours among the Romans - subscribed to by some contemporary scholars of the Gospel of John ${ }^{24}$ - was essentially wrong. The Romans did not really have two systems of reckoning hours but rather two systems for determining the beginning and end of a day (dies): (1) an official, legal one per-

23 W.M. Ramsay, "About the Sixth Hour," The Expositor. Series 4 7/3 (1893) 219: "The civil Day was not divided into hours; it was a purely religious, legal, and scientific entity, and did not affect in any way popular division of time. [...] Such expressions as 'the first hour,' 'the sixth hour,' have then only one meaning."

24 William Hendriksen (Exposition, 104) goes as far as to suggest that the way of reckoning hours among the Romans was contingent on the region: "contemporary records do not make clear just where the one method of figuring the hours ended and the other began. Usage probably differed in different regions." 
taining to dies civilis (that is, our modern conception of a 24-hour calendar day) - reckoned from midnight to midnight, and (2) an everyday, commonly-used one pertaining to dies naturalis or dies verus - considered as the period from dawn till dusk. But the Romans always had only one way of counting the hours of a day: a day was comprised of 12 hours counted from sunrise. ${ }^{25}$

Additional light is shed on the Roman system of reckoning hours by the sort of sundials mentioned in Censorinus' text. Tellingly, on Roman sundials, noon is marked by the figure VI, and not XII. ${ }^{26}$ For example, a Roman poet, Persius (34-62 CE), in his third Satire $(3,5)$, mentions sleeping late when "the line is touched by the fifth shadow," referring to a sundial indicating 11 a.m. ${ }^{27}$ Thus, sundials themselves confirm that hours were counted from sunrise and not from midnight. A division of the day into twelve hours was introduced in the wake of the invention of the sundial and became widespread only in the mid- $2^{\text {nd }}$ century BCE..$^{28}$

These conclusions are corroborated by present-day scholars of ancient Rome. Let me refer to their stances concerning only the 1 st and the 10th hours. The $O x$ ford Companion to Classical Literature states that "[t]he Romans when they spoke of "the first hour' meant as a rule the point of time when the first hora from sunrise was completed." 29 Then the Oxford Latin Dictionary defines decima as the tenth hour of the Roman day calculated from sunrise, that is 4 p.m. ${ }^{30}$ Jérôme Carcopino similarly posits that in Roman calculations the tenth hour (hora deci-

25 Ramsay, "About the Sixth Hour," 220. In his second article on the topic, William Ramsay ("The Sixth Hour," The Expositor. Series $53 / 6$ [1896] 458) argues: "Even when a Roman was describing a civil Day, or series of civil Days, he still counted his 'first hour' as beginning from sunrise; and he called mid-night, which was the beginning of his twenty-four hours day, "the sixth hour of the night."' Moreover, the Roman civil day as such was not divided into hours. A similar stance is expressed by Arthur Wright (Some New Testament Problems, 157): "It is not legitimate, I maintain, to assert any longer that there were two ways of reckoning hours. The controversy has been unnecessarily confused by introducing into it the question of the point in the twenty-four hours at which the day legally begins. But that is an entirely separate matter. The Roman day, like our own, legally began at midnight, the Jewish day at sunset; but the Romans reckoned the hours from sunrise, exactly as did the Jews, the Greeks, and the rest of the civilized world."

26 P. Harvey, The Oxford Companion to Classical Literature (Oxford: Clarendon 1937) 88; Morris, The Gospel According to John, 138, n. 91.

27 The Latin text: "Nempe haec adsidue. iam clarum mane fenestras intrat et angustas extendit lumine rimas. stertimus, indomitum quod despumare Falernum sufficiat, quinta dum linea tangitur umbra" (LCL 91,74). English translation: "I suppose this is now routine. Already the bright morning is coming through the shutters, enlarging the narrow cracks with light. We're snoring enough to make the untamed Falernian stop fizzing, while the shadow reaches the fifth line" (LCL 91, 75). On the same page, the editor added an explanatory footnote: "Falernian was a powerful wine from Campania."

28 L. Schmitz, "Hora," A Dictionary of Greek and Roman Antiquities (ed. W. Smith) (London: Murray 1875) 614.

29 Harvey, The Oxford Companion to Classical Literature, 88.

30 P. Glare, Oxford Latin Dictionary, 2 ed. (Oxford: Oxford University Press 2012) 490. 
$\mathrm{ma}$ ) during the winter solstice denoted the period from 2:13 to 2:58 p.m. The tenth hour at the summer solstice in turn lasted from 3:46 to 5:02 p.m. ${ }^{31}$

\subsection{Geographical-Chronological Argument}

Scholars who claim the presence of a distinctively Roman reckoning of hours in the Gospel of John frequently make use of a geographical argument. Ephesus, for example, the capital of the Roman province of Asia (which covered western Asia Minor), is where, according to the patristic tradition, the Gospel of John was created. There, some have argued, the hours were supposedly counted starting from midnight. The inhabitants of Asia Minor, despite their being Greeks, are believed to have embraced a Roman system of reckoning hours, as subjects of Rome. ${ }^{32}$

The geographical argument in favor of the Roman hypothesis is necessarily related to the period when the Gospel of John was created, which is the end of the first century CE. What is more, as scholars point out, the vast majority of that Gospel's addressees were heathens. John then would have no need to refer to a (supposedly different) Jewish reckoning of hours, which would have been alien to his readers, but instead would have every reason to employ the Roman system already familiar to pagans. ${ }^{33}$

31 J. Carcopino, Daily Life in Ancient Rome. The People and the City at the Height of the Empire (Peregrine Books 23; Middlesex, U.K. - Ringwood, Australia: Penguin Books 1956) 168. It can be assumed that the event described in John 1:39 takes place in February or March, which falls in the winter months preceding the springtime observance of the Passover mentioned in John 2:13. See M.-É. Boismard, Du Baptême à Cana (Jean, 1, 19 - 2, 11) (LD 18; Paris: Cerf 1956) 73.

32 A conviction that Ephesus was thoroughly Roman is exhibited by Guy Rogers (The Sacred Identity of Ephesos. Foundation Myths of a Roman City [London: Routledge 1991] 141), who states: "it is extremely difficult to find even one area of Ephesian institutional or social life documented in the huge epigraphical corpus of the city in which Roman presence [...] was not pervasive or persistent by the end of the first century AD." See also W. Carter, John and Empire. Initial Explorations (New York - London: Clark 2008) 58-64.

33 Archibald T. Robertson (Word Picture, s.v. John 1:39) argued: "John in Ephesus at the close of the century naturally uses Roman time." In the same vein, William Milligan and William F. Moulton ("The Gospel of John," A Popular Commentary on the New Testament by English and American Scholars of Various Evangelical Denominations with Illustrations and Maps. II. The Gospel of John and the Acts [ed. P. Schaff] [New York: Scribner's Sons - Edinburgh: Clark 1880] 17) state: "Further investigation has shown that at the very time when this book was written a mode of computation substantially agreeing with our own [i.e. British] was known in Asia Minor (where John wrote) and elsewhere. It is easy to see that in such a matter as this a writer naturally follows the custom of those amongst whom he lives, and whom he has immediately in view as his readers." Also George W. Clark (The Gospel of John [A People's Commentary; Philadelphia, PA: American Baptist Publication Society 1896] 41) argues: "This view [Roman hypothesis] also accords with the fact that John wrote for the people (primarily for the Christians) of Asia Minor, and that they were largely unacquainted with, and unaccustomed to, the Jewish mode of reckoning." See also Hendriksen, Exposition, 104-105. 
A similar argument was made by Alan Culpepper, who placed emphasis not so much on the time when the Gospel was created but on the language of its readers and their knowledge of contemporary geography. The American scholar draws attention to the necessity John faced of explaining to a pagan audience concepts well known to the Jews, such as "rabbi" (1:38), "messiah" (1:41) and "rabboni" (20:16). Similarly, the place-name "Sea of Tiberias" (after the Galilean capital of Herod Antipas) was more familiar to the addressees of the Book of John than the

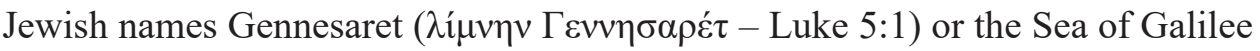


pepper maintains therefore that John's usage of the hypothesized Roman mode of reckoning hours would have been more familiar both to the narrator and the reader of the Gospel of John. He argues: "The Roman system [...] fits both the chronological references and the data regarding locales and languages better than the Jewish system." ${ }^{\prime 34}$

Another piece of evidence offered for a distinctively Roman system of reckoning hours (i.e., from midnight) is a description of the martyrdom of Polycarp, the bishop of Smyrna, a city located in Asia Minor. According to Acta martyrum, Polycarp died at the "eighth hour" (The Martyrdom of Polycarp 21). ${ }^{35}$ As some scholars see it, the context of the reference indicates that the eighth hour here means in the morning. ${ }^{36}$ Later, and again in Smyrna, Pionius the presbyter died a martyr's death during the rule of the Emperor Decius $(250 \mathrm{CE})$, at the "tenth hour." By the same token, some scholars believe that the tenth hour cannot correspond to 4 p.m., as typically such deaths took place before noon. ${ }^{37}$

The argument based on Acta martyrum sketched above - i.e., treating the eight hour, (the time of Polycarp's death) as 8 a.m. (and not 2 p.m.), and the tenth hour (the time of Pionius' death) as 10 a.m. (and not 4 p.m.) - is not convincing to everyone. For example, William Ramsay argues that both these hours should be understood as afternoon hours. As regards Polycarp, William Ramsay (drawing on the very same work - The Martyrdom of Polycarp) claims that his death took place after the end of that day's public competitions in the arena, including

34 Culpepper, Anatomy, 219. The geographical argument is also embraced by E.E. Whitfield. In his note to William Kelly's explanation of the sixth hour in John 19:14 (An Exposition of the Gospel of John, 2 ed. [Edited, with Additions, by E.E. Whitfield] [London: Elliot Stock 1908] 534), Whitfield assumes the existence of the Roman reckoning of hours both in Rome and in Asia: "If the Roman reckoning differed in Italy and the Roman province of Asia Minor, the third hour of Mark living in Italy would be identical with 'about the sixth hour' of John living at Ephesus in his old age."

35 Text: E.C.E. Owen (trans. and ed.), Some Authentic Acts of the Early Martyrs (Oxford: Clarendon 1927) 41.

36 Westcott, The Gospel According to St. John, 282. Blomfield Jackson (St. Polycarp, Bishop of Smyrna [Early Church Classics; London: SPCK 1898] 72, n. 3) noted: "Either 8 a.m., counting from midnight; or 2 p.m. counting from 6 a.m. The former is the more probable."

37 Westcott, The Gospel According to St. John, 282. 
fights with wild animals, events which could not possibly have been completed by the early morning hours (before 8 a.m.). Specifically, following Polycarp's examination and confession before the Roman proconsul, the crowd calls for a lion to be loosed upon him, whereupon the superintendent (asiarch) states that he is legally prevented from doing so, because he had "closed the Sports." Settling instead on burning as the means of death, the preparation of the stake and pyre then occupied a certain amount of time. Moreover, on the day of his execution Polycarp had to be transported from his place of arrest (a villa outside of the city) into Smyrna, where he was put to death. Covering such a distance also required some time. ${ }^{38}$

The interpretation of the times of Polycarp's and Pionius' deaths as occurring in the afternoon is buttressed by certain other ancient texts. Sacred Tales by the Greek orator Aelius Aristides (117-181 CE) confirm the reckoning of hours from sunrise within Asia Minor in the 2nd century CE. It is worth noting that Aristides not only lived in Smyrna but was a contemporary of Polycarp (69-156 CE) - he might well have encountered the saint in the city's streets! $!^{39}$ In his first speech we read that, having been told by a deity to bathe, Aristides

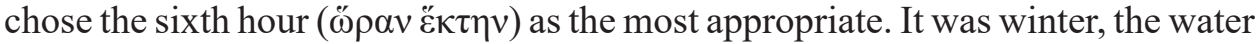
was cold, and the sixth hour was the warmest time of the day. The text leaves no doubt that his bath occurs at midday, as it mentions the shadow starting to return. ${ }^{40}$ Then in his fifth speech, Aristides recounts his dream in which the sun over the agora ( $\dot{\varepsilon} \kappa \tau \tilde{\eta} \varsigma \dot{\alpha} \gamma o \rho \tilde{\alpha} \varsigma)$ commands him to make a speech in the place

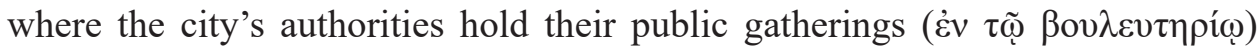

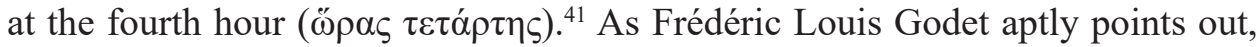
the fourth hour can only be 10 a.m., when the agora was filled with the city's inhabitants. ${ }^{42}$ It is clear, then, that in Polycarp's time, in Smyrna - and more broadly in Asia Minor in the time of John the Evangelist - the hours of the day were counted from sunrise. To summarize, the examples from the two speeches of Aelius Aristides given above indicate that, in the $2^{\text {nd }}$ century CE in Smyrna, the hours of the day were counted beginning from dawn.

38 Ramsay, "About the Sixth Hour," 220-223. As regards the tenth hour (that is 4 p.m.) as the time of Pionius' martyrdom, William Ramsay (p. 223) claims: "We may explain the lateness of the hour by supposing, (1) that his trial was not first on the list for the day; (2) that it took a considerable time, being protracted by the torture inflicted on him; (3) that the preparations for burning him took longer time than in the case of Polycarp; (4) that he had to be conducted from the court to the place of execution."

39 F. Godet, Commentary on the Gospel of St. John (Edinburgh: Clark 1879) I, 442: "a Greek Sophist of the second century, a contemporary of Polycarp, whom he may have met in the streets of Smyrna."

40 Aelius Aristides, Aristides ex recensione Guilielmi Dindorfii (Lipsaie: Libraria Weidemannia - Reimer 1829) I, 450.

41 Aelius Aristides, Aristides, I, 542.

42 Godet, Commentary, 442. 
An additional argument supporting the claim that the Greeks counted the hours from sunrise may be found in a much older text of another Greek author, Aristophanes (445-385 BCE). His work Ecclesiazusae (no. 652) in-


feet long $(\delta \varepsilon \kappa \tilde{\alpha} \pi \circ 0 \varsigma)$, indicating the tenth hour. ${ }^{43}$ Writing also in the $5^{\text {th }}$ century BCE, Herodotus (484-425 BCE) argued: "the sunclock and the sundial, and the twelve divisions of the day, came to Hellas not from Egypt but from Babylonia" (The Persian Wars II, 109; LCL 117, 399). ${ }^{44}$ Making reference to Herodotus' text, the $19^{\text {th }}$ century author Thomas Whitelaw argued: "the Greeks of Asia Minor no less than the Jews, Babylonians, and Romans reckoned their day from sunrise to sunset or from 6 A.M. to 6 P.M." ${ }^{45}$

It is curious, then, that Georg Fridrich Unger would state that in Pergamon and the western part of Asia Minor (thus including both Smyrna and Ephesus) a Macedonian system of counting 24 hours from sunrise to sunrise was used. ${ }^{46}$ As we have amply demonstrated, the Macedonian mode of reckoning hours would in fact be identical with the Jewish one (and, indeed, the Roman) as to determining the hours of the day (dies naturalis).

To conclude, the Roman and Greek texts discussed above refute the geographical-chronological argument. It turns out that both the Romans and the Greeks counted the hours of the day from sunrise, and the hours of the night from sunset.

\section{Arguments Supporting the Existence of the Jewish System of Reckoning Hours}

The fact that the Jews counted hours from sunrise to sunset is corroborated by a fragment of The Mishnah (Sanh. 5,3). The text cites the opinion of Rabbi Judah whereby testimonies of the same event given by two different witnesses are both accepted, on account of the fact that one of them mentions the third hour and the other the fifth hour as the time of the event. Nevertheless, the Rabbi


to scent yourself, and to go and dine, when the shadow of the gnomon is ten feet long on the dial" (TLG). Cf. L. Schmitz, "Horologium," A Dictionary of Greek and Roman Antiquities (ed. W. Smith) (London: Murray 1875) 615-617.


B $\alpha \beta \nu \lambda \omega v i ́ \omega v \varepsilon \ddot{\mu} \mu \alpha \theta$ ov oi "E $\lambda \lambda \eta v \varepsilon \varsigma$ (LCL 117, 398).

45 T. Whitelaw, The Gospel of St. John. An Exposition Exegetical and Homiletical, for the Use of Clergymen, Students, and Teachers (New York: Dutton 1888) 40. In the same vein, Johann P. Lange (The Gospel According to John, 93) argues: "The Greeks of Asia Minor, for whom John wrote, had with the Jews the Babylonian reckoning, from sun-rise to sun-set."

46 G.F. Unger, “Tages Anfang,” Philologus 51 (1892) 14-45 and 212-230. 
rejects two other testimonies in which one witness mentions the fifth hour and the other the seventh hour, "since at the fifth hour the sun is in the east and at the seventh it is in the west." ${ }^{47}$ Clearly, in the text mentioned above the third hour corresponds to 9 a.m., the fifth hour would be 11 a.m., and the seventh hour is 1 p.m. ${ }^{48}$

Looking to the Gospel of Matthew, the parable about workers in the vineyard (20:5-12) also makes use of the Jewish mode of counting hours since sunrise and also clearly shows the division of the day into twelve hours. The final hour of labor starts at the "eleventh hour" and lasts till the evening (20:8). Those employed last, at the eleventh hour, only worked for one hour (20:12). The implication is that the last hour of the day is the twelfth hour. While one may reasonably posit that the Gospel of Matthew reflects the way of reckoning hours used in Jesus' time, that mode was unquestionably known to the addressees of the Gospel living in the second half of the $1^{\text {st }}$ century CE.

The description of Jesus Christ's crucifixion in the Gospel of Mark contains three precise references to the hours of the day. Jesus was crucified at the "third hour" (15:25), and there was darkness between the sixth and the ninth hours (15:33). Clearly, Mark has used the standard Jewish mode of reckoning hours here, since it is inconceivable for the crucifixion to have taken place at 3 a.m.

Returning momentarily to the separate question of the beginning (and end) of a day, exegetes debating this point as it relates to the biblical literature all mention only two alternatives: dawn or dusk. Conspicuously absent from the discussion, however, is any notion of a Roman system of counting the hours from midnight. Though it would be directly relevant, such is never mentioned as pointing to an alternative, i.e. a biblical day beginning at midnight. ${ }^{49}$ John Henry Bernard refers to the text of Flavius Josephus (Vita 54), which mentions the Jewish habit

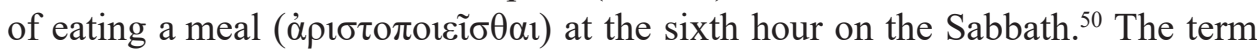

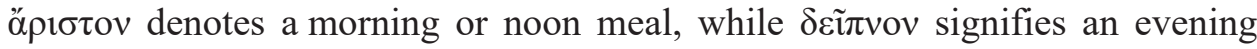

47 Text of Mishnah after H. Danby, The Mishnah Translated from the Hebrew with Introduction and Brief Explanatory Notes (Oxford: Oxford University Press 1933) 389. The example given by Morris, The Gospel According to John, 138.

48 Craig S. Keener (Gospel of John. A Commentary [Peabody, MA: Hendrickson 2003] 470, n. 394) points also to Exodus Rabba 41:7 as an example of counting hours from 6 a.m.

49 P.J. Heawood, "The Beginning of the Jewish Day," JQR 36/4 (1946) 393-401 (prefers the "morning theory"); S. Zeitlin, "The Beginning of the Jewish Day during the Second Commonwealth," JQR 36/4 (1946) 403-414 (before the Babylonian exile, the morning; in the post-exilic period, the evening); H.R. Stroes, "Does the Day Begin in the Evening or Morning? Some Biblical Observations," VT 16 (1966) 460-475 (prefers the evening); J.A. McGuire, "Evening or Morning: When Does the Biblical Day Begin?" AUSS 46/2 (2008) 201-214 (prefers the "evening theory").

50 J.H. Bernard, A Critical and Exegetical Commentary on the Gospel According to St John (ICC; Edinburgh: Clark 1928) I, 56. 
meal. ${ }^{51}$ We must assume, then, that the sixth hour at which the meal was eaten was midday, and the hours of the day were counted since sunrise.

To conclude, rabbinical and biblical literature (both the Old and New Testaments), as well as the writings of Flavius Josephus, all make use of the Jewish system of reckoning the hours of the day, namely from sunrise to sunset. It seems logical then that John would use the same system of reckoning hours as present in other books of the New Testament. ${ }^{52}$

\section{The Application of Both Hypotheses to John's Text}

John 1:39. The espousal of the Roman system as regards the "tenth hour" in

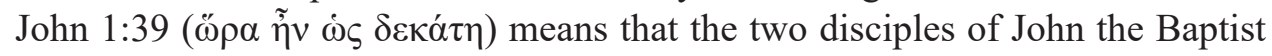
would meet Jesus at 10 a.m. The following arguments are given to support this point of view.

First, a morning setting for the calling of Andrew and another unnamed disciple makes chronological "room" for the other events of that day as described in the Gospel, such as Andrew's meeting with Peter (1:41), Andrew's bringing Peter to Jesus (1:42a), and Peter's meeting with Jesus (1:42b) ${ }^{53}$ The ancient Syrian translation (Codex Sinaiticus Syriacus) as a matter of fact adds the expression "that day" in 1:41, suggesting the continuity of events in 1:39 (Andrew's meeting with Jesus) and in 1:41 (Andrew's meeting with Peter).$^{54}$ The fact that all these events transpired on one day is also suggested by the Greek text of the Gospel, which uses the word "next day" ( $\tau \tilde{\eta} \tilde{\varepsilon} \pi \alpha u ́ p ı v)$ in 1:43.

Secondly, if the tenth hour is treated as an afternoon one (as per the usual Jewish reckoning), it becomes difficult to understand the statement that Andrew and

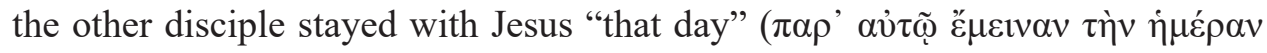
$\dot{\varepsilon} \kappa \varepsilon i ́ v \eta v-1: 39)$. "That day" needs to last longer than the two late afternoon hours

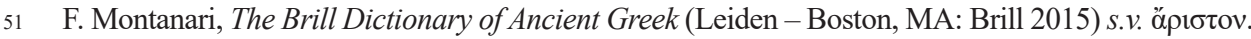

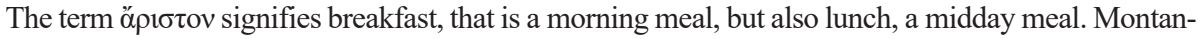

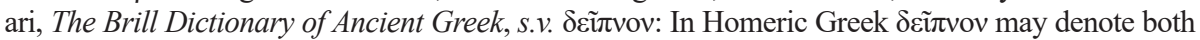

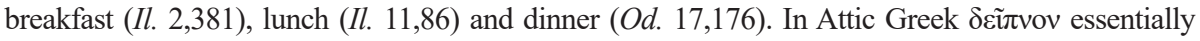
signifies an evening meal (Sophocles, Aeschylus).

52 Cf. A. Plummer, The Gospel According to S. John, with Maps, Notes and Introduction (CGTS; Cambridge: Cambridge University Press 1896) 84; R.H. Lightfoot, St. John's Gospel. A Commentary (Oxford: Clarendon 1956) 103; J. Blinzler, The Trial of Jesus. The Jewish and Roman Proceedings against Jesus Christ (Westminster, MD: Newman Press 1959) 267; Morris, The Gospel According to John, 138.

53 Westcott, The Gospel According to St. John, 24: "“that day' [...] appears to have been full of incident"; Plummer, The Gospel According to S. John, 84; B. Lindars, The Gospel of John (NCB; London: Marshall, Morgan \& Scott 1972) 114: "[10 a.m.] would allow time for Andrew to find Peter."

54 Barrett, The Gospel According to St John, 181. 
(from 4 to 6 p.m.). ${ }^{55}$ If the tenth hour was 4 p.m., John would presumably write instead that the two disciples remained with Jesus "that evening" (cf. Luke 24:29). ${ }^{56}$

Thirdly, it has been suggested, a morning hour better suits the intentions of the traveling Jesus, since he would prefer to reach his destination in the morning rather than in the late afternoon. ${ }^{57}$ This last argument is difficult to accept, though: Why would a traveler want to reach his destination as early as 10 a.m.? In any event, one's time of arrival is always contingent on when they departed and the distance covered. In the case of travel to distant places, the journey may last many days, and the traveler would want to make best use of their time every day till the evening. As an example, consider the pilgrimage from Galilee to Jerusalem, a common multi-day journey in New Testament times. The arrival at each day's destination would clearly be planned for the afternoon or evening hours.

Fourth, staying with Jesus for a longer period would enable a lengthy interaction between him and his disciples. It is only a morning hour that would give the disciples practically the whole day to interact with Jesus. ${ }^{58}$ Once again, it is a weak argument based on a contrived, wished-for narrative (or time-frame).

Reinforcing such views, Edgar Bruns states that "the arguments of those who believe John is using the official [Roman] method appear superior." ${ }^{59}$ Now, however, we turn to arguments scholars have made against understanding the "tenth hour" in John 1:39 as reflecting a supposed Roman system and in favor of the known Jewish system of reckoning hours, that is as 4 p.m.

First, Andrew and the unnamed disciple could well have stayed with Jesus for the whole evening and night. As a result, the events described in the following verses $(1: 41-42)$, those involving Peter, could have taken place on the next day. ${ }^{60}$ "On the next day" (1:43) would then refer to the following day (day three), distinct from that referred to in 1:39 (day one) and in 1:41-42 (day two).

Secondly, scholars note that staying with someone through late afternoon can be commonly referred to as being with them "that day," especially when

55 Lange, The Gospel According to John, 93; Westcott, The Gospel According to St. John, 282; Walker, "The Reckoning of Hours," 69; Barrett, The Gospel According to St John, 181: "4 p.m. - not a natural point for the beginning of a day's stay."

56 Hendriksen, Exposition, 105.

57 Westcott, The Gospel According to St. John, 282: "It is an hour by which a wayfarer would seek to have ended his journey."

58 Westcott, The Gospel According to St. John, 282: "it would leave practically 'a day' for intercourse"; Lindars, The Gospel of John, 114: "[it] would give the whole day for the disciples' stay"; Gundry, Commentary, 354: “'The tenth hour' from midnight, then, is ten o'clock in the morning; and staying with Jesus 'that day,' most of which remained, carries more meaning, a meaning that better symbolizes a permanent abiding in Christ."

59 J.E. Bruns, "The Use of Time in the Fourth Gospel," NTS 13 (1967) 286.

60 Boismard, Du Baptême à Cana, 73-74; U.C. von Wahlde, The Gospel and Letters of John. II. Commentary on the Gospel of John (ECC; Grand Rapids, MI: Eerdmans 2010) 62. 
the conversation continued into the night. ${ }^{61}$ The expression that the disciples stayed with Jesus "that day" constitutes a contrast to the idea of a short visit, which the disciples had most likely intended to pay. ${ }^{62}$

Thirdly, Barnabas Lindars argues that the question as to whether the "tenth hour" is a morning or an afternoon one is related to the larger question of the historical accuracy of the Gospel of John. That is, to what extent is John's account historically correct as it has come down to us? In his view, this detail is so simple that it should be understood in the most obvious and straightforward way: as the "Jewish" tenth hour, i.e. 4 p.m. ${ }^{63}$ On the other hand, the British exegete sees the detail as a typical element for structuring a story. In his view, it is a mere narrative device by means of which the disciples become part of Jesus' entourage, to accompany him on the way to Galilee (1:43). In light of this, Barnaba Lindars posits that the afternoon hour is more likely to have been the intention of the narrator. ${ }^{64}$

John 4:6. Jesus" meeting with the Samaritan woman took place at the "sixth

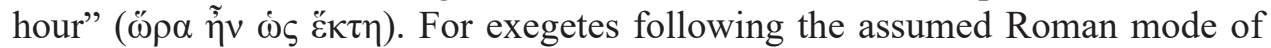
reckoning hours - i.e., counting 12 hours starting from either midnight or midday, depending on the context - this is taken to be $6 \mathrm{p} . \mathrm{m}$. There are a few reasons why some scholars view the alleged Roman system as better in this case than the conventional Jewish one - according to which the sixth hour would be noon. First, women are depicted in the Bible as coming to the well in the evening (see Gen 24:11). Noon, in the heat of the day, was an unusual hour for the strenuous work of drawing water. Secondly, Jesus was sitting at the well, tired from his journey, his exhaustion suggesting the end of a full day's travel. Thirdly, the evening seems a better moment for the disciples to purchase the provisions (John 4:8) ${ }^{65}$ and for a communal meal. ${ }^{66}$ Fourthly, as Alfred Plummer notes, "noon was an unusual hour for travelling. ${ }^{\circ 67}$

61 Lange, The Gospel According to John 93: "Even of a late part of the afternoon it may be said in popular speech, that they abode with Him that day, especially if the conversation extended into the night"; M.R. Vincent, Word Studies in the New Testament. II. The Writings of John, the Gospel, the Epistles, the Apocalypse (Grand Rapids, MI: Eerdmans 1887) 72: "John would not have been unlikely to use a looser and more popular form of speech in indicating the length of the stay with Jesus, meaning simply that they remained with him during the remainder of the day, and, no doubt, prolonged their conversation into the night."

62 Godet, Commentary, 442.

63 Lindars, The Gospel of John, 114: "it appears so artless that it must be taken at its face value"; F.J. Moloney, Belief in the Word. Reading the Fourth Gospel, John 1-4 (Minneapolis, MN: Fortress 1993) 68, n. 54: "The reference to 'the tenth hour' is to be taken at its face value, that is, about 4:00 p.m.”; F.J. Moloney, The Gospel of John (SP 4; Collegeville, MN: Liturgical Press 1998) 54.

64 Lindars, The Gospel of John, 114.

65 Westcott, The Gospel According to St. John, 282; Walker, “The Reckoning of Hours,” 70; Culpepper, Anatomy, 219.

66 Gundry, Commentary, 365: "that hour suits the disciples' going into town to buy food for an evening meal (4:8), whereas Jews didn't eat a lunch."

67 Plummer, The Gospel According to S. John, 116. 
There are, however, just as convincing arguments in favor of understanding the sixth hour as noon, in accordance with the known Jewish system. These include the following:

First, midday seems more understandable in the context of John's characterization of Jesus. The Gospel reads here that Jesus is wearied from his journey (4:6). He is also thirsty, as he addresses the woman with the following words: "give me a drink" (4:7). Some contemporary scholars believe that the heat of the noon hour better explains Jesus' tiredness and thirst for water ${ }^{68}$ Actually, the description makes sense regardless of the system of reckoning hours, that is Roman (6 p.m.) or Jewish (noon).

Secondly, the sixth hour being midday would give plenty of time for Jesus' conversation with the Samaritan woman, then dealing with his disciples, and finally encountering the inhabitants of the city of Sychar, who came in huge numbers. As Alfred Plummer notes, "after 6 P.M. there would be rather short time for all that follows." ${ }^{69}$

Thirdly, according to Edgar Bruns, noon is a better moment for a meal than either 6 a.m. or sunset. ${ }^{70}$ Joachim Jeremias maintains that typically two meals were partaken of daily: a simple breakfast between 10 and 11 in the morning and the main meal (dinner) in the late afternoon. ${ }^{71}$ The Talmud (b. Pes. 12b) posits that the sixth hour (midday) is a time when people typically have their meal. According to Flavius Josephus (Vita 279) though, it was only on the Sabbath that the meal was eaten at the sixth hour, that is at midday. Other Talmudic texts (b. Pes. 107b) and the targum on Eccl 10:16-17 suggest that the first meal was eaten at 10 a.m. According to yet another Talmudic text, b. Shab. 10a, the fourth hour (10 a.m.) is breakfast time for laborers, while it is the fifth hour (11 a.m.) for other people. ${ }^{72}$ In any event, it would be difficult to expect Jesus and his disciples to abide by any of these customs while on the road.

Fourth, it is true that women used to draw water from a well in the evening, in order to avoid the heat of noon. The account, however, suggests that the Samaritan woman is alone by the well with Jesus. The time of noon would in fact explain her solitude. Sometimes the unusual noontime hour of her visit to the well is explained by reference to her embarrassment with her own sinfulness and, as a result, her desire to avoid critical comments addressed to her by the other

68 Barrett, The Gospel According to St John, 231: "If, as is probable, by the sixth hour he meant noon, the tiredness and thirst of Jesus are readily understandable."

69 Plummer, The Gospel According to S. John, 116.

70 Bruns, "The Use of Time in the Fourth Gospel," 287: "noon appears to be a most appropriate hour for Jesus to feel the heat of the sun and to wish for rest and refreshment. Since it was also the customary hour for eating, the departure of the disciples to procure food is also intelligible."

71 J. Jeremias, The Eucharistic Words of Jesus (Philadelphia, PA: Fortress 1977) 44-45.

72 Jeremias, The Eucharistic Words of Jesus, 44-45, n. 7. 
women of Sychar. ${ }^{73}$ The text is ambiguous, however, and does not make it possible to unequivocally assess the woman's moral stance. ${ }^{74}$

John 4:52. The son of a nobleman was healed at "the seventh hour" (ळ丷 $\rho \alpha v$ $\varepsilon \beta \delta$ '́ $\mu \eta v-4,52)$. This hour was also the time of the nobleman's meeting with Jesus. Applying the usual Jewish system of reckoning hours, the healing and the meeting took place at 1 p.m. In accordance with the hypothesized Roman one, it was either 7 a.m. or 7 p.m.

The morning hour (7 a.m.) is not plausible, since the father - following his morning meeting with Jesus - would reach Capernaum on the same day and could not meet his servants on the way the following day, as per the text. Thus, for adherents of the Roman reckoning, the evening hour (7 p.m.) is seen as more likely. The father of the healed son would have sufficient time between morning and the evening meeting with Jesus ( 7 p.m.) to travel from Capernaum to Cana, where Jesus was at that time. The following day, after spending the night in Cana, the father would be returning to Capernaum and would meet his servants on the way. ${ }^{75}$

The Roman hypothesis is also able to explain John's text if the literal meaning


as Jesus said: "your son is alive." The evening time of the meeting (7 p.m.), that is, a time already after dusk, assumes that the father set out and traveled during the night, reaching Capernaum after midnight, that is, on the following day. He would then, under this scenario, also have met his servants sometime after midnight, on "the next day." Alfred Plummer believes, however, that it "is improbable" for the man to meet Jesus in the evening, since "the servants would meet him before midnight. Thus the modern [i.e. Roman] method of reckoning from midnight to midnight does not suit." ${ }^{, 76}$

73 Plummer, The Gospel according to S. John, 116: "a woman whose life was under a cloud (v. 18) might select an unusual hour; and at 6 P.M. numbers would probably have been coming to draw, and the conversation would have been disturbed."

74 H.W. Attridge, "The Samaritan Woman. A Woman Transformed," Character Studies in the Fourth Gospel. Narrative Approaches to Seventy Figures in John (eds. S.A. Hunt - D.F. Tolmie - R. Zimmermann) (Grand Rapids, MI: Eerdmans 2016) 272: "Some readers have taken a cue from the time of the encounter that the Samaritan is perhaps of loose morals, and hence to be imagined as something of a hussy, since the normal times for drawing water would not be at the sixth hour (probably around noon). But the data are ambiguous, it might be shame that sends the Woman out at an unusual hour, or it might be modesty or simple necessity. If shame motivates the timing of her trip, she might be asked to move with head bowed, dispirited and defensive in her demeanor."

75 Westcott, The Gospel According to St. John, 292; Walker, "The Reckoning of Hours," 70; Culpepper, Anatomy, 219. Robert H. Gundry (Commentary, 371) offers yet another interpretive possibility which supports the Roman reckoning: "Since 'yesterday' implies that the slaves stayed overnight in Cana after a day's walk from Capernaum (about twenty miles away), 7:00 P.M. seems the more likely time of Jesus" "word."

76 Plummer, The Gospel According to S. John, 128. 
In light of the Jewish hypothesis, the meeting and the healing occurred at


the father, after meeting Jesus, started on his return journey from Cana to Capernaum. It is difficult to determine whether the distance between these two places can be covered between 1 p.m. and the evening. It seems rather unlikely in light of the data conveyed by Flavius. ${ }^{77}$ The text mentions that the father meets his servants on the following day when he is still on the way (4:51). It can be assumed that the father would not be likely to loiter and would continue to travel even after dusk, which - according to the Jewish system of reckoning days was already the next day. It would be after dusk, then, that he would meet his servants, who had left Capernaum immediately after $1 \mathrm{p} . \mathrm{m}$. They would meet halfway between Cana and Capernaum. Alternatively, one might guess - again, overlooking the literal meaning of v. 50 - that the father, being exhausted after his journey, would have stayed in Cana after his meeting with Jesus in order to eat and recover his strength. He would then set out on his journey at dawn and meet his servants. ${ }^{78}$ Either scenario works just as well in terms of the hours and days.

As Raymond E. Brown aptly notes, we do not have full insight into the event. Did the father really embark on his return journey immediately after his meeting with Jesus? ${ }^{79}$ Maybe he was so tired after the day's journey that he had to stay overnight in Cana, or somewhere between Cana and Capernaum. The text does not need to include all the details. Its "unreliability" in terms of details is corroborated by the basic discrepancy in rendering the identity of the one asking for healing and the one healed: the Synoptics write here of a Roman centurion and his sick servant, while in John's text it is a nobleman who pleads with Jesus to heal his son.

The seventh hour seems to be compatible with the message of the text according to both the Jewish and the supposed Roman system of reckoning hours (1 p.m. and 7 p.m., respectively). As Edgar Burns points out, the time of day or night does not matter for a desperate father seeking help for his dying son. ${ }^{80}$

77 Flavius Josephus (Vita 90) mentions his trip from Cana to Tiberias, which took him the whole night

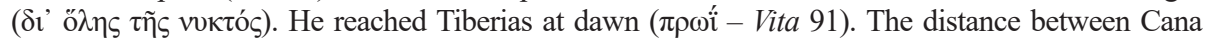
and Capernaum is similar. Brook F. Westcott is of a different opinion (The Gospel According to St. John, 282) as he states: "The uncertainty of the site of Cana causes a little difficulty in determining the time required for the journey from Capernaum to Cana. This may however be fairly reckoned at about four or five hours."

78 Alfred Plummer (The Gospel According to S. John, 128) suggests that the father "would scarcely start at once in the mid-day heat; nor would the servants." Anyway, even if the father and the servants started their journeys in the cool afternoon, they met up after sunset and they might speak of "seventh hour" (1 p.m.) as "yesterday."

79 R.E. Brown, The Gospel According to John (i-xii). Introduction, Translation, and Notes (AB 29; Garden City, NY: Doubleday 1966) 191: "there are many unknown factors. Did he set out immediately?"

80 Bruns, "The Use of Time in the Fourth Gospel," 287. Some authors would also point out that there is no certainty regarding the geographical location of Cana in the Gospel of John. As a result, any 
John 11:9. The Jewish mode of reckoning hours is supposedly evinced in the statement: "Are there not twelve hours in the day? If anyone walks in the day, he does not stumble, because he sees the light of this world" (John 11:9) ${ }^{81}$ The twelve hours of day would then be counted from sunrise. The argument is not completely convincing, as the text does not indicate the precise moment from which the hours of the day are counted. Brooke Foss Westcott noted also that "[t]he mention of 'twelve hours in the day' has no bearing on the decision one way or other; for we commonly use the same phrase though we reckon from midnight to noon." $" 82$

John 19:14. A problem that is frequently raised by scholars is the incongruence between Mark's remark of Jesus' crucifixion at "the third hour" (15:25) and John's account of Pilate sentencing Jesus to death at about "the sixth hour" ( $\omega \rho \alpha$ $\tilde{\eta} \vee \omega \varsigma \check{\varepsilon} \kappa \tau \eta-19: 14) .{ }^{83}$ One way to explain this apparent discrepancy posits that the two texts deploy different systems of reckoning hours. John is argued to have used the Roman method of counting the hours from midnight, his sixth hour then being 6 a.m., while Mark would use the Jewish system of counting the hours from dawn, his third hour thus corresponding to 9 a.m..$^{84}$ This way, the three hours between the passing of the sentence ( 6 a.m.) and the crucifixion ( 9 a.m.) would be sufficient for the events described in the gospels that came between the sentencing and the crucifixion (e.g. Jesus' being derided, and his death-march to Golgotha).

This argument can be rejected, however, based on an analysis of the entire scope and sequence of events. In John's account, Jesus had an initial hearing before Pilate (18:33), was scourged (19:1) and mocked (19:2-3), then underwent a further interrogation (19:9) - all before Pilate announced his verdict at (per the Roman hypothesis) 6 a.m. In Luke's text, Jesus was also sent by Pilate to see Herod Antipas (23:8-12) before the sentence was announced (23:35). It is quite difficult to imagine all these events having taken place before 6 a.m. - especially high officials hearing a case in the wee hours of the morning, and especially

conclusions regarding the time of the healing based on the distance between Capernaum and Cana can only be hypothetical. Actually, the only real candidates for the location of Cana are the modern town of Kafar Kanna (Kfar Kenna) and the nearby ancient site of Khirbet Qana (Khirbet Cana) - and the two are exactly equidistant from Capernaum, $23 \mathrm{~km}$ (as the crow flies). See L.J. Hoppe, "Cana of Galilee: The Two Candidates", TBT 48/3 (2010) 161-167.

81 Lange, The Gospel According to John, 93; Vincent, Word Studies, 71.

82 Westcott, The Gospel According to St. John, 282. Cf. also Hendriksen, Exposition, 105, n. 46.

83 J. Finegan, Handbook of Biblical Chronology. Principles of Time Reckoning in the Ancient World and Problems of Chronology in the Bible, Revised Edition (Peabody, MA: Hendrickson 1998) 359: "Mark 15:25 and John 19:14 are 'plainly unreconcilable' and Mark 15:35 [sic!] can even be thought to be an "interpolation."'

84 Hutcheson, An Exposition, 398; Robertson, Word Pictures, ad loc.; Hendriksen, Exposition, 105; Walker, "The Reckoning of Hours," 70. 
during springtime.$^{85}$ This difficulty of the press of events disappears, however, if we accept the normal Jewish system of reckoning hours. Then, Pilate would announce his verdict at noon.

William M. Ramsay argues against the validity of attempts to harmonize the accounts of Mark and John based on the supposed two systems of reckoning the hours. In antiquity, Ramsay contends, people were not interested in a precise measurement of time, but instead specified hours in a rather arbitrary way. They were generally limited to using the following designations: early hour (morning), third, sixth, ninth, and late (evening) hour. ${ }^{86}$ John's sixth hour may in fact signify any time between, say, 11 a.m. and 1 p.m. If, for example, the crucifixion took place at 10:30 a.m., Mark could have specified this time as the third hour (i.e., roughly mid-morning), while John remembered it as the sixth hour. They would both be reporting in good faith and would be convinced of the reliability of the data they conveyed. ${ }^{87} \mathrm{In}$ short, perhaps there is no compelling need to reconcile Mark and John on this point at all. Still, the above argument referring to the four times of the day is not fully convincing, in light of the Gospel of John itself, which mentions the tenth hour (1:39) and the seventh hour (7:54). Matt 20:6 mentions, moreover, the eleventh hour. Another problem that arises is the need to use the same word "hour" to refer both to each of the twelve equal divisions of the day and also to the four larger parts of the day. ${ }^{88}$ If, however, William Ramsay's hypothesis is to be embraced as valid, John's precise specification of the two hours mentioned above (seventh and tenth) could be treated as carrying some symbolic significance.

The Roman hypothesis would also seem to align with the information that Jesus was brought from Caiaphas to Pilate early "in the morning" ( $\tilde{\eta} v \delta \dot{\varepsilon} \pi \rho \omega \hat{i}-$ John 18:28; see Mark 15:1). The term $\pi \rho \omega \hat{~}$ may denote the final, i.e. fourth,

85 R. Lenski, The Interpretation of St. John's Gospel (Minneapolis, MN: Augsburg 1961) 150; R.E. Brown, The Gospel According to John (xiii-xxi). Introduction, Translation, and Notes (AB 29A; Garden City, NY: Doubleday 1970) 883: "Jesus can scarcely have been brought to Pilate at the daybreak hour (close to 6 a.m.), have undergone an extended trial, including scourging and mocking, and still have received his sentence at 6 a.m."; Keener, Gospel of John, 1130: "this [Roman] reckoning [...] allows too little time from sunrise (near 18:28) for the events preceding the condemnation."

86 A.J. Köstenberger, John (BECNT; Grand Rapids, MI: Baker Academic 2004) 75: "the day was divided into three-hour intervals, with people approximating the estimated time to the next full threehour segment."

87 Ramsay, "About the Sixth Hour," 217-218; Wright, Some New Testament Problems, 152. The constantly shifting balance of daylight versus darkness as the seasons progress (i.e., summer "hours" are in fact considerably longer, and winter ones shorter) might be another major factor that would have introduced considerable fluidity and imprecision into time references in antiquity, before mechanical time-keeping.

88 S. Witetschek, "The Hour of the Lamb? Some Remarks on John 19,14 and the Hour of Jesus's Condemnation and/or Crucifixion," Jesus, John, and History. III. Glimpses of Jesus through the Johannine Lens (eds. P.N. Anderson - F. Just - T. Thatcher) (ECL 18; Atlanta, GA: SBL Press 2016) 99. 
night watch, that is, a time between 3 a.m. and 6 a.m. (see Mk 13:35) ${ }^{89}$ However, the adverb $\pi \rho \omega \hat{~}$ used in John 18:28 may also signify late morning. Theophrastus of Eresos (370-287 BCE), in his work De Signis Tempestatum 9, defines $\pi \rho \omega \hat{i ́ ~ a s ~}$ the period between sunrise ( $\dot{\alpha} v \alpha \tau o \lambda \eta)$ and noon $(\mu \varepsilon \sigma \eta \mu \beta \rho i ́ \alpha) \cdot{ }^{90}$ If the writers of the Gospel wish to use $\pi \rho \omega \hat{~}$ to signify a period at night (the fourth night watch),

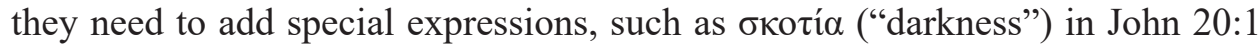

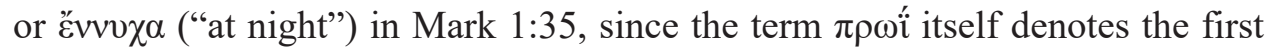
hour of day. In the case of John 18:28, the term $\pi \rho \omega$ is not qualified any further, which means that Jesus was brought to Pilate in the early or late morning. What is more, if Jesus is brought to Pilate in the morning, that is, $\pi \rho \omega \hat{~}(18: 28)$, he cannot possibly be sentenced at practically the same morning time, that is at 6 a.m. following the alleged Roman system of reckoning..$^{11}$ According to John 19:14, the day of Jesus' crucifixion was the preparation day for the Passover ( $\tilde{\eta} v \delta \grave{\varepsilon}$

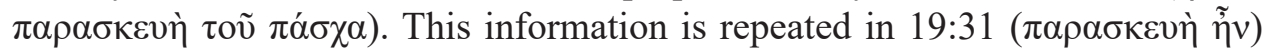
in the context of the necessity of removing Jesus' body from the cross, and in

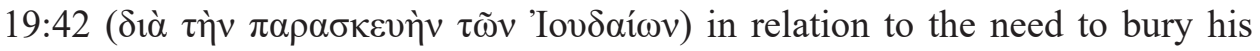
body in a timely manner. The preparation day is the Friday before the Sabbath (see 19:31), and the Passover in the year in which Jesus was crucified (AD 33) in fact fell on a Sabbath. As Raymond E. Brown notes, "it is quite clear in the Johannine account of Jesus' death that the next day, the Passover, would begin in early evening, and not at midnight; this detail favors a reckoning of the night hours from 6 p.m., and the daylight hours from 6 a.m.."92

Some commentators have also tried to reconcile the texts of Mark and John through reference to a mistake of the scribe, who in John 19:14, instead of the third hour (written as the letter gamma: $\Gamma$ ) wrote the sixth hour (written as a graphically similar digamma: F). ${ }^{93}$ As a matter of fact, there are manuscripts of the Gospel


believes that a scribe's mistake may have occurred already within the presumed Hebrew source text: "through the use of a Hebrew sign which in square char-

89 BDAG, s.v. $\pi \rho \omega \hat{i} ;$ J.H. Thayer, A Greek-English Lexicon of the New Testament (New York - Cincinnati, OH - Chicago, IL: American Book 1886) 554.

90 H.G. Liddell - R. Scott, A Greek-English Lexicon, 9 ed. (Oxford: Clarendon 1996) s.v. $\pi \rho \omega \hat{t}$.

91 K. Wengst, Das Johannesevangelium. II. Teilband: Kapitel 11-21, 2 ed. (ThKNT 4/2; Stuttgart: Kohlhammer 2007) 262, n. 185.

92 Brown, The Gospel According to John (i-xii), 75.

93 Such a proposal was put forward already by the Fathers of the Church: Eusebius of Caesarea (PG 22, 1009), Epiphanius of Salamis, Ammonius of Alexandria (PG 85, 1512). For a detailed analysis see S. Witetschek, "Die Stunde des Lammes? Christologie und Chronologie in Joh 19,14," ETL 87/1 (2011) 128-132.

94 See the discussion of the issue in B.M. Metzger, A Textual Commentary on the Greek New Testament. A Companion Volume to the United Bible Societies' Greek New Testament (Fourth Revised Edition) (Stuttgart: Deutsche Bibelgesellschaft 1994) 216. 
acter is waw (6), but on some old coins gimel (3)" ${ }^{95}$ However, this hypothesis of a scribal error, and thereby the reading of "the third hour" in John 19:14, is rejected as an obvious example of lectio facilior, a forced attempt at harmonizing the account with Mark 15:25.96

Another explanation of the discrepancy between Mark's and John's accounts relies on the attribution of certain intentions to the writers, who would have wanted to indicate a precise hour for theological or symbolic reasons. Mark, for example, perhaps sought to emphasize the darkness that befell the world at noon (15:33). John, in turn, may have wanted to connect the moment of Jesus' death with the moment the sheep were offered at the Passover ${ }^{97}$, or simply to point out that Jesus" "hour" has come (cf. 2:4) ${ }^{98}$

\section{Conclusion}

The article analyzes two solutions that are sometimes offered - one set against the other - to the "problem" of the Johannine mode of reckoning the hours of the day. Taking a hint from the methodology of critica textus, I would call them examples of "internal criticism" and "external criticism." By the former, I understand the application of the Roman and Jewish methods of reckoning the hours of the day to the text of the Gospel of John. By the latter, I mean the scrutiny of the ancient sources pertinent to the whole issue of how the hours were in fact reckoned in the time of Jesus and at the time and place of the writing of John's Gospel.

Referring to the internal evidence, scholars differ in their conclusions. Their opinions seem to be based not only on personal biases but also on a flair for interpretative creativity and exegetical deftness. It is sufficient to mention only

95 Barrett, The Gospel According to St John, 545.

96 Metzger, A Textual Commentary, 216.

97 R.E. Brown, Death of the Messiah. From Gethsemane to the Grave. A Commentary on the Passion Narratives in the Four Gospels (ABRL; New York: Doubleday 1994) 847 ("One may wonder whether John's readers would have understood this symbolism, but it is commonly held that leading members of the Johannine community had been ejected from the synagogue and knew Jewish customs well"); Wengst, Das Johannesevangelium, 262. This popular hypothesis has been strongly countered by Witetschek, "Die Stunde des Lammes?" 127-187; Witetschek, "The Hour of the Lamb?" 95-107.

98 Some scholars embrace both explanations, e.g., Barrett, The Gospel According to St John, 545; J. Beutler, Das Johannesevangelium. Kommentar (Freiburg im Breisgau: Herder 2013) 495. Some

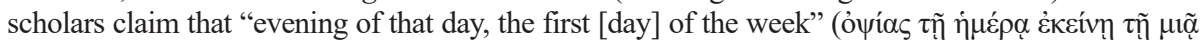
$\sigma \alpha \beta \beta \alpha \dot{\alpha} \tau \omega v)$ in John 20:19 definitely refers to the Roman day. See Robertson, Word Pictures, s.v. ("clearly Roman time"); Hendriksen, Exposition, 105 ("In 20:19 the author must mean the Roman day"). They do not explain, however, why this should be the case. The text does not speak about reckoning of hours. 
three randomly chosen contemporary authors as examples. Craig Keener argues that the Roman system is "unlikely" in 1:39 and that it "fits 19:14 better but not 4:6." ${ }^{\prime 99}$ Alfred Plummer observes that none of the instances where John mentions the hour of the day is decisive: "in no single case is the balance of probability strongly in favour of the modern [i.e. Roman] method." ${ }^{100}$ Eventually, he is convinced that John embraced the Jewish method. Robert H. Gundry, however, opts for the asserted Roman reckoning as fitting the text of the Gospel best. ${ }^{101}$ Thus, resorting to the internal manner of argumentation is pointless, since the results produced seem to be inconclusive, if not contradictory.

In light of the above, the second option - applying the technique of external criticism - seems to lead to more solid and promising ground. Donald A. Carson maintains that the arguments on behalf of the Roman system of reckoning are "unconvincing." 102 In my view, the numerous arguments presented above which stem from analysis of the ancient sources - the external connections - indicate that John definitely employed the well-attested, standard Jewish system of reckoning the hours of the day. This view is shared by many contemporary scholars. To give only one example, Edward W. Klink III states: "The evidence almost unanimously supports understanding the time system to be Jewish and not Roman." ${ }^{103}$ Even Brooke Foss Westcott, himself a promoter of the Roman hypothesis in the Gospel of John, believes that the Greeks, Romans and Jews all typically counted hours since dawn, ${ }^{104}$ while the Roman system was "unusual in ancient times." 105

Richard Lenski notes that " $[\mathrm{t}]$ he best students have wrestled with the question as to how John calculates his hours." 106 This statement seems to imply the virtual impossibility of finding a proper, satisfying solution to the vexing question of the Johannine way of reckoning the hours of the day. Similarly, Charles Kingsley Barrett argued that "[i]t is impossible to settle with complete certainty the method of enumerating the hours employed by John." 107 In my understanding, however, the whole discussion about the mode of reckoning the hours in the Gospel of John - and consequently the perceived need to solve this "problem" - arose from

99 C.S. Keener, The IVP Bible Background Commentary. New Testament (Downers Grove, IL: InterVarsity 1993) ad loc.

100 Plummer, The Gospel According to S. John, 84.

101 Gundry, Commentary, 354, 365, 371, 451. See also Clark, The Gospel of John, 41: "There seems to be internal evidence in John's Gospel that he adopted the common Roman reckoning."

102 Carson, The Gospel According to John, 157.

103 E.W. Klink III, John (ZECNT; Grand Rapids, MI: Zondervan 2016) 146, n. 7.

104 Westcott, The Gospel According to St. John, 282: "The Romans (Mart. 4:8) and Greeks, no less than the Jews, reckoned their hours from sunrise."

105 Westcott, The Gospel According to St. John, 282.

106 Lenski, The Interpretation, 149.

107 Barrett, The Gospel According to St John, 231. 
a misunderstanding of, or even an ignorance of, the ancient extrabiblical sources. As shown above, the Roman system of reckoning the hours of the day (dies naturalis) was in fact one: the day started with sunrise. Thus, the choice between two methods or systems turns out to have been a false alternative to start with. Put another way, it is an artificially created alternative, since its existence simply cannot be corroborated by ancient sources. The conviction that there was in antiquity a "Roman" system whereby the hours of the day were counted from midnight surfaced within exegetical literature itself, and only in relatively modern times, as we have shown. And the seeds of this misconception lie in inadequate scholarship, specifically the fact that no distinction was made between the reckoning of hours and the reckoning of days (24-hour days) or - to be more precise the determination of the beginning of the day. While the Romans in fact had two systems of marking the beginning of the day (dies civilis, legitimus - starting at midnight, and dies naturalis, verus - starting at sunrise), the manner of reckoning the hours of the day and the night was the same for the Romans and for the Jews. Simply put, there was only one system, nearly universal in the ancient world, for counting the hours. This conclusion is neither new nor original. Already in 1825 Ludwig Ideler wisely wrote in his chronology textbook:

However much the Babylonians, Egyptians, Greeks, and Romans, diverged from each other in the epoch of the civil day, they were as uniform in their reckoning of the hours. The whole year through, they divided the natural day and the night into twelve hours, which they reckoned from the rising of the sun to its setting, and from its setting to its rising; so that noon came at the beginning of the seventh hour of the day, and midnight at the beginning of the seventh hour of the night. ${ }^{108}$

In light of this, it is astounding that contemporary scholars of the Gospel of John perpetuate the mistaken notion of the existence in antiquity of two different systems for reckoning the hours of the day.

To conclude, the Gospel of John counts the hours of the day in the way common in all of the ancient world, that is, beginning from dawn. The tenth hour in 1:39 corresponds to what we now conceive of as 4 p.m., the sixth hour in 4:6 and 19:14 is 12 p.m. (noon), while the seventh hour in 4:52 should be under-

108 L. Ideler, Handbuch der mathematischen und technischen Chronologie aus den Quellen bearbeitet (Berlin: Rücker 1825) I, 84: “die Babylonier, Aegypter, Griechen und Römer in der Epoche des bürgerlichen Tages von einander abweichen mochten, so übereinstimmig war ihre Stundenrechnung. Sie legten nämlich das ganze Jahr hindurch dem natürlichen Tage sowohl als der Nacht zwölf Stunden bei, die sie von Aufgange der Sonne bis zu ihrem Untergange, und vom Untergange bis zu ihrem Aufgange fortzählten, so dass der Mittag auf den Anfang der siebenten Tages- und die Mitternacht auf den Anfang der siebenten Nachtstunde traf." English translation after E.W. Hengstenberg, Commentary on the Gospel of St John (Edinburgh: Clark 1865) I, 92-93. 
stood as 1 p.m. As for the discrepancy between Mark 15:25 and John 19:14 which may be more apparent than real, a projection of our own modern preoccupation with time - its explanation must be sought elsewhere.

\section{Bibliography}

Aelius Aristides, Aristides ex recensione Guilielmi Dindorfii (Lipsaie: Libraria Weidemannia Reimer 1829).

Attridge, H.W., "The Samaritan Woman. A Woman Transformed," Character Studies in the Fourth Gospel. Narrative Approaches to Seventy Figures in John (eds. S.A. Hunt - D.F. Tolmie R. Zimmermann) (Grand Rapids, MI: Eerdmans 2016) 268-281.

Aulus Gellius, Attic Nights. I. Books 1-5 (trans. and ed. J.C. Rolfe) (Loeb Classical Library 195; Cambridge, MA: Harvard University Press 1927).

Barnes, A., Notes on the New Testament. Luke and John (London: Blackie \& Son 1885).

Barrett, C.K., The Gospel According to St John. An Introduction with Commentary and Notes on the Greek Text, 2 ed. (London: SPCK 1978).

Bernard, J.H., A Critical and Exegetical Commentary on the Gospel According to St John (The International Critical Commentary on the Holy Scriptures of the Old and New Testaments; Edinburgh: Clark 1928).

Beutler, J., Das Johannesevangelium. Kommentar (Freiburg im Breisgau: Herder 2013).

Blinzler, J., The Trial of Jesus. The Jewish and Roman Proceedings against Jesus Christ (Westminster, MD: Newman Press 1959).

Blum, E.A., "John," The Bible Knowledge Commentary. An Exposition of the Scriptures by Dallas Seminary Faculty. Old Testament and New Testament Edition Based on the New International Version (eds. J.F. Walvoord - R.B. Zuck) (Wheaton, IL: Victor Books 1983) II, 266-348.

Boismard, M.-É., Du Baptême à Cana (Jean, 1, 19 - 2, 11) (Lectio divina 18; Paris: Cerf 1956).

Brant, J-A.A, John (Paideia: Commentaries on the New Testament; Grand Rapids, MI: Baker Academic 2011).

Brodersen, K. (trans. and ed.), Censorinus. Über den Geburtstag. Lateinisch und Deutsch (Edition Antike; Darmstadt: Wissenschaftliche Buchgesellschaft 2012).

Brown, R.E., Death of the Messiah. From Gethsemane to the Grave. A Commentary on the Passion Narratives in the Four Gospels (The Anchor Bible Reference Library; New York: Doubleday 1994).

Brown, R.E., The Gospel According to John (i-xii). Introduction, Translation, and Notes (The Anchor Bible 29; Garden City, NY: Doubleday 1966).

Brown, R.E., The Gospel According to John (xiii-xxi). Introduction, Translation, and Notes (The Anchor Bible 29A; Garden City, NY: Doubleday 1970).

Bruce, F.F., The Gospel of John. Introduction, Exposition and Notes (Grand Rapids, MI: Eerdmans 1983).

Bruns, J.E., "The Use of Time in the Fourth Gospel," New Testament Studies 13 (1967) 285-290.

Caesar, Alexandrian War. African War. Spanish War (trans. and ed. A.G. Way) (Loeb Classical Library 402; Cambridge, MA: Harvard University Press 1955). 
Carcopino, J., Daily Life in Ancient Rome. The People and the City at the Height of the Empire (Peregrine Books 23; Middlesex, U.K. - Ringwood, Australia: Penguin Books 1956).

Carson, D.A., The Gospel According to John (The Pillar New Testament Commentary; Grand Rapids, MI - Cambridge, U.K.: Eerdmans 1990).

Carter, W., John and Empire. Initial Explorations (New York - London: Clark 2008).

Clark, G.W., The Gospel of John (A People's Commentary; Philadelphia, PA: American Baptist Publication Society 1896).

Cook, W.F., John. Jesus Christ is God (The Focus on the Bible Commentary Series; Fearn, Rossshire, Scotland, U.K.: Christian Focus 2016).

Culpepper, R.A., Anatomy of the Fourth Gospel. A Study in Literary Design (Philadelphia, PA: Fortress 1983).

Danby, H., The Mishnah. Translated from the Hebrew with Introduction and Brief Explanatory Notes (Oxford: Oxford University Press 1933).

Ferraro, G., L'“ora” di Cristo nel quarto vangelo (Aloisiana 10; Roma: Herder 1974).

Finegan, J., Handbook of Biblical Chronology. Principles of Time Reckoning in the Ancient World and Problems of Chronology in the Bible, Revised Edition (Peabody, MA: Hendrickson 1998).

Frey, J., Die johanneische Eschatologie. II. Das johanneische Zeitverständnis (Wissenschaftliche Untersuchungen zum Neuen Testament 110; Tübingen: Mohr Siebeck 1998).

Glare, P. (ed.), Oxford Latin Dictionary, 2 ed. (Oxford: Oxford University Press 2012).

Godet, F., Commentary on the Gospel of St. John (Edinburgh: Clark 1879) I.

Grafton, A.T., “Time-reckoning," The Oxford Companion to Classical Civilization, 2 ed. (eds. S. Hornblower - A. Spawforth) (Oxford: Oxford University Press 2014) 793-794.

Gundry, R.H., Commentary on the New Testament. Verse-by-Verse Explanations with a Literal Translation (Peabody, MA: Hendrickson 2010).

Haenchen, E., John 1. A Commentary on the Gospel of John, Chapters 1-6 (Hermeneia. A Critical and Historical Commentary on the Bible; Philadelphia, PA: Fortress 1984).

Harvey, P. (ed.), The Oxford Companion to Classical Literature (Oxford: Clarendon 1937).

Heawood, P.J., "The Beginning of the Jewish Day," The Jewish Quarterly Review. New Series 36/4 (1946) 393-401.

Hendriksen, W., Exposition of the Gospel According to John (Baker New Testament Commentary; Grand Rapids, MI: Baker Book House 1953, reprint 2002).

Hengstenberg, E.W., Commentary on the Gospel of St John (Edinburgh: Clark 1865).

Herodotus, The Persian Wars. I. Books 1-2 (trans. A.D. Godley) (Loeb Classical Library 117; Cambridge, MA: Harvard University Press 1920).

Hoppe L.J., "Cana of Galilee: The Two Candidates", The Bible Today 48/3 (2010) 161-167.

Horace, Satires. Epistles. The Art of Poetry (trans. and ed. H.R. Fairclough) (Loeb Classical Library 194; Cambridge, MA: Harvard University Press 1926).

Hutcheson, G., An Exposition of the Gospel of Jesus Christ According to John (London: Smith 1657). Ideler, L., Handbuch der mathematischen und technischen Chronologie aus den Quellen bearbeitet (Berlin: Rücker 1825).

Jackson, B., St. Polycarp, Bishop of Smyrna (Early Church Classics, London: SPCK 1898).

Jeremias, J., The Eucharistic Words of Jesus (Philadelphia, PA: Fortress 1977).

Jojko, B., "The Hour of Jesus and the Wedding Feast at Cana (John 2:1-11)," Verbum Vitae 38/1 (2020) 125-147. DOI: https://doi.org/10.31743/vv.11245 
Juvenal, Persius, Juvenal and Persius (ed. and trans. S.M. Braund) (Loeb Classical Library 91; Cambridge, MA: Harvard University Press 2004).

Keener, C.S., Gospel of John. A Commentary (Peabody, MA: Hendrickson 2003).

Keener, C.S., The IVP Bible Background Commentary. New Testament (Downers Grove, IL: InterVarsity 1993).

Kelly, W., An Exposition of the Gospel of John, 2 ed. (Edited, with Additions, by E.E. Whitfield). (London: Elliot Stock 1908).

Klink III, E.W., John (Zondervan Exegetical Commentary on the New Testament; Grand Rapids, MI: Zondervan 2016).

Köstenberger, A.J., John (Baker Exegetical Commentary on the New Testament; Grand Rapids, MI: Baker Academic 2004).

Lange, J.P., The Gospel According to John (A Commentary on the Holy Scriptures. New Testament 3; New York, NY: Scribner 1871).

Lenski, R., The Interpretation of St. John's Gospel (Minneapolis, MN: Augsburg 1961).

Léon-Dufour, X., Lecture de l'Évangile selon Jean. IV. L'heure de la glorification (chapitres 18-21) (Paris: Seuil 1996).

Liddell, H.G. - Scott, R., A Greek-English Lexicon, 9 ed. (Oxford: Clarendon 1996).

Lightfoot, R.H., St. John's Gospel. A Commentary (Oxford: Clarendon 1956).

Lindars, B., The Gospel of John (New Century Bible; London: Marshall, Morgan \& Scott 1972).

Livy, History of Rome. IV. Books $8-10$ (trans. B.O. Foster) (Loeb Classical Library 191; Cambridge, MA: Harvard University Press 1926).

Martial, Epigrams. I. Spectacles, Books 1-5 (ed. and trans. D.R. Shackleton Bailey) (Loeb Classical Library 94; Cambridge, MA: Harvard University Press 1993).

Maude, W., De Die Natale, by Censorinus (New York: Cambridge Encyclopedia 1900).

McGuire, J.A., "Evening or Morning: When Does the Biblical Day Begin?" Andrews University Seminary Studies 46/2 (2008) 201-214.

Metzger, B.M., A Textual Commentary on the Greek New Testament. A Companion Volume to the United Bible Societies' Greek New Testament, 4 ed. (Stuttgart: Deutsche Bibelgesellschaft 1994).

Mihalios, S., The Danielic Eschatological Hour in the Johannine Literature (Library of New Testament Studies 436; London - New York: Clark 2011).

Milligan, W. - Moulton, W.F., "The Gospel of John," A Popular Commentary on the New Testament by English and American Scholars of Various Evangelical Denominations with Illustrations and Maps. II. The Gospel of John and the Acts (ed. P. Schaff) (New York: Scribner's Sons - Edinburgh: Clark 1880) 1-242.

Moloney, F.J., Belief in the Word. Reading the Fourth Gospel, John 1-4 (Minneapolis, MN: Fortress 1993).

Moloney, F.J., The Gospel of John (Sacra Pagina 4; Collegeville, MN: Liturgical Press 1998).

Montanari, F., The Brill Dictionary of Ancient Greek (Leiden - Boston, MA: Brill 2015).

Morris, L., The Gospel According to John, Revised Edition (The New International Commentary on the New Testament; Grand Rapids, MI: Eerdmans 1995).

Mounce, R.H., "John," The Expositor's Bible Commentary. Revised Edition. X. Luke - Acts (eds. T. Longman III - D.E. Garland) (Grand Rapids, MI: Zondervan 2007) 357-661.

O'Conor, W.A., A Commentary on the Gospel of St. John (London: Longmans - Green 1874).

Owen, E.C.E. (trans. and ed.), Some Authentic Acts of the Early Martyrs (Oxford: Clarendon 1927). 
Parker, H.N., Censorinus. The Birthday Book (Chicago, IL: University of Chicago Press 2007).

Pliny, Natural History. I. Books 1-2 (trans. H. Rackham) (Loeb Classical Library 330; Cambridge, MA: Harvard University Press 1938).

Plummer, A., The Gospel According to S. John, with Maps, Notes and Introduction (Cambridge Greek Testament for Schools; Cambridge: Cambridge University Press 1896).

Plutarch, Moralia. IV. Roman Questions. Greek Questions. Greek and Roman Parallel Stories.

On the Fortune of the Romans. On the Fortune of the Virtue of Alexander. Were the Athenians More Famous in War of in Wisdom? (ed. F.C. Babbitt) (Loeb Classical Library 305; Cambridge, MA: Harvard University Press 1936).

Ramsay, W.M., “About the Sixth Hour,” The Expositor. Series 4 7/3 (1893) 216-223.

Ramsay, W.M., "The Sixth Hour," The Expositor. Series 5 3/6 (1896) 457-459.

Rogers, G.M., The Sacred Identity of Ephesos. Foundation Myths of a Roman City (London: Routledge 1991).

Robertson, A.T., Word Pictures in the New Testament. V. The Fourth Gospel (Nashville, TN: Broadman 1932).

Schaff, P. (ed.), A Select Library of the Nicene and Post-Nicene Fathers of the Christian Church. XIV. Saint Chrysostom: Homilies on the Gospel of St. John and the Epistle of Hebrews (New York: Christian Literature 1889).

Schmitz, L., "Hora," A Dictionary of Greek and Roman Antiquities (ed. W. Smith) (London: Murray 1875) 614.

Schmitz, L., "Horologium," A Dictionary of Greek and Roman Antiquities (ed. W. Smith) (London: Murray 1875) 615-617.

Stroes, H.R., "Does the Day Begin in the Evening or Morning? Some Biblical Observations," Vetus Testamentum 16 (1966) 460-475.

Thayer, J.H., A Greek-English Lexicon of the New Testament (New York - Cincinnati, OH - Chicago, IL: American Book 1886).

Unger, G.F., "Tages Anfang,” Philologus 51 (1892) 14-45 and 212-230.

Utley, R.J., The Beloved Disciple's Memoirs and Letters. The Gospel of John, I, II, and III John (Study Guide Commentary Series. New Testament 4; Marshall, TX: Bible Lessons International 1999).

Vincent, M.R., Word Studies in the New Testament. II. The Writings of John, the Gospel, the Epistles, the Apocalypse (Grand Rapids, MI: Eerdmans 1887).

von Wahlde, U.C., The Gospel and Letters of John. II. Commentary on the Gospel of John (The Eerdmans Critical Commentary; Grand Rapids, MI: Eerdmans 2010).

Walker, N., "The Reckoning of Hours in the Fourth Gospel," Novum Testamentum 4 (1960) 69-73.

Wengst, K., Das Johannesevangelium. II. Teilband: Kapitel 11-21, 2 ed. (Theologischer Kommentar zum Neuen Testament 4/2; Stuttgart: Kohlhammer 2007).

Westcott, B.F., The Gospel According to St. John. The Authorized Version with Introduction and Notes (London: Murray 1882).

Whitelaw, T., The Gospel of St. John. An Exposition Exegetical and Homiletical, for the Use of Clergymen, Students, and Teachers (New York: Dutton 1888).

Wiersbe, W.W., The Bible Exposition Commentary (Wheaton, IL: Victor Books 1996).

Witetschek, S., "Die Stunde des Lammes? Christologie und Chronologie in Joh 19,14," Ephemerides Theologicae Lovanienses 87/1 (2011) 127-187. 
Witetschek, S., "The Hour of the Lamb? Some Remarks on John 19,14 and the Hour of Jesus's Condemnation and/or Crucifixion," Jesus, John, and History. III. Glimpses of Jesus through the Johannine Lens (eds. P.N. Anderson - F. Just - T. Thatcher) (Early Christianity and Its Literature 18; Atlanta, GA: SBL Press 2016) 95-107.

Wright, A., Some New Testament Problems (The Churchman's Library; London: Methuen 1898).

Zeitlin, S., "The Beginning of the Jewish Day during the Second Commonwealth," The Jewish Quarterly Review. New Series 36/4 (1946) 403-414. 